\title{
Projecting expansion range of Selaginella zollingeriana in the Indonesian archipelago under future climate condition
}

\author{
AHMAD DWI SETYAWAN ${ }^{1,2, \vartheta}$, JATNA SUPRIATNA ${ }^{3}$, NISYAWATI ${ }^{3}$, ILYAS NURSAMSI $^{4}$, SUTARNO $^{2}$, \\ SUGIYARTO $^{2}$, SUNARTO $^{1,2}$, PRAKASH PRADAN ${ }^{5}$, SUGENG BUDIHARTA $^{6}$, ARI PITOYO ${ }^{2}$, \\ SAPTA SUHARDONO ${ }^{1}$, PRABANG SETYONO ${ }^{1}$, MUHAMMAD INDRAWAN $^{1}$ \\ ${ }^{1}$ Department of Environmental Science, Faculty of Mathematics and Natural Sciences, Universitas Sebelas Maret. Jl. Jend. Urip Sumoharjo No. 179, \\ Surakarta 57128, Central Java, Indonesia. Tel.: +62-271-663375, `email: volatileoils@ gmail.com \\ ${ }^{2}$ Department of Biology, Faculty of Mathematics and Natural Sciences, Universitas Sebelas Maret. Jl. Ir. Sutami 36A, Surakarta 57126, Central Java, \\ Indonesia \\ ${ }^{3}$ Department of Biology, Faculty of Mathematics and Natural Sciences, Universitas Indonesia. J1. Lingkar Akademik, Depok 16424, West Java, Indonesia \\ ${ }^{4}$ School of Earth and Environmental Science, Faculty of Science, The University of Queensland. St Lucia 4072, Brisbane, Queensland, Australia \\ ${ }^{5}$ West Bengal Biodiversity Board, Department of Environment, Government of West Bengal, Salt Lake, Sector-III, FD415A, Poura Bhawan, 4th Floor, \\ Kolkata, West Bengal, India \\ ${ }^{6}$ Purwodadi Botanic Gardens, Indonesian Institute of Sciences. J1. Raya Surabaya-Malang Km. 65, Purwodadi, Pasuruan 67163, East Java, Indonesia
}

Manuscript received: 5 January 2020. Revision accepted: 29 March 2021.

\begin{abstract}
Setyawan AD, Supriatna J, Nisyawati, Nursamsi I, Sutarno, Sugiyarto, Sunarto, Pradan P, Budiharta S, Pitoyo A, Suhardono S, Setyono P, Indrawan M. 2021. Projecting expansion range of Selaginella zollingeriana in the Indonesian archipelago under future climate conditions. Biodiversitas 22: 2088-2103. The expansion of plant species to outside areas of its original localities has attracted great interest in theoretical ecology. The scientific curiosity of such phenomenon is even deeper when the geographical expansion is confined by natural boundaries and affected by environmental changes, including climates. This study aimed to predict the current suitable habitat niche of Selaginella zollingeriana Spring, a species with original distribution in Java Island, and to project its potential suitable niche in the Indonesian archipelago accounting for future climate conditions. In doing so, we applied the Ecological Niche Modelings (ENMs) using MaxEnt algorithm by employing 30 presence data of $S$. zollingeriana and twelve enviro-climatic variables. The model predicted around $17.22 \%\left(22,095 \mathrm{~km}^{2}\right)$ of the Java Island area is potentially suitable for current habitat niche of $S$. zollingeriana, consisting of $10.93 \%\left(14,028 \mathrm{~km}^{2}\right), 4.75 \%\left(6,097 \mathrm{~km}^{2}\right)$, and $1.54 \%\left(1,970 \mathrm{~km}^{2}\right)$ of low, medium, and high suitability areas, respectively. Under future scenarios, the model predicted the possibility of species expansion into the other four big islands (i.e., Sumatera, Borneo, Sulawesi, and Papua). Nonetheless, the model also predicted a declining trend of the availability of suitable niches wherein from 2030 to 2080 the modeled niche declined about 58\% and 59\% under the most optimistic and most pessimistic climate change projections, respectively. While this study provides a primary example in predicting species expansion in tropical archipelago, similar studies in a range of contexts (e.g., species, region) are recommended to add more evidence to strengthen the theoretical ground of expansion ecology under climate changes.
\end{abstract}

Keywords: Climate change, endemic plant, Indonesia, Selaginella zollingeriana

\section{INTRODUCTION}

Plant species expansion is an ecological phenomenon that represents the proliferation, spread, and persistence of species transported by various means (e.g., human activities, animals, wind) to new and potentially distant ranges. Classic diffusion theory of species expansion typically considers scenarios of symmetrical, radial expansion from a central point, the speed of which is determined by the dispersal ability and reproductive rate of the population (Skellam 1951). The radial expansion of species theoretically occurs either at a constant rate that increases linearly along time, or at an accelerating rate wherein the distances gained increase each year (Shigesada et al. 1995). Theoretical and empirical approaches to analyzing range expansion have highlighted the importance of intra-species interactions, evolution, long-range dispersal events, temporal variability, and spatial heterogeneity as factors that significantly influence the expansion process (reviewed in Hastings et al. 2005). Furthermore, landscape structure and configuration are also particularly crucial since few expanded landscapes are homogenous and geographical boundaries can restrict the extent of the expanded range (With 2002; LaMorgia et al. 2011). While model study typically focuses on range expansion from a single point of introduction, multiple introduction points are more coherent since it can enhance the likelihood of establishment and can ensure expansion range increase in heterogeneous landscape bounded by coastline, such as Indonesia (e.g. Kolbe et al. 2004; Miller et al. 2005; Urban et al. 2008; Zalewski et al. 2010; Sakai et al. 2001).

The $21^{\text {st }}$ century experienced the most robust global warming of the last millennium, and future temperature rises are likely to exceed this trend with a predicted increase of between $1.7^{\circ} \mathrm{C}$ and $4{ }^{\circ} \mathrm{C}$ until the end of the century (Solomon et al. 2007). The potential impact of these rapid changes of climate on the conservation and 
distribution of biodiversity is something that must become an object of great concern. One of the major effects is that animal and plant species worldwide might move to higher latitudes and elevations in response to deviate off the enviro-climatic conditions to which they are adapting (Parmesan 2006). Several model-based projections suggested that the expected future climate conditions would allow many species to expand their current distribution range several hundred kilometers towards higher latitudes and/or elevations within a few decades (Skov and Svenning 2004; Struebig et al. 2015). Much ambiguity exists, however, to which extent species will be capable of achieving such large-scale expansions in pace with rapid changes of climate. The answer to this question might include wide-ranging ecological and evolutionary consequences spanning from the population to the biome level. Therefore, the expansion process might strongly affect the wider-range genetic structure of species and the potential adaptability of their populations (Excoffier et al. 2009). The discrepancies in migration capacity of species should result in considerable reshufflings of local and regional communities of species (Ackerly 2003; Jackson et al. 2009), and the expansion of biomes with its components will directly influence future climate, be it as a mitigating (e.g., by cloistering CO2) or an exacerbating force (Bonan 2008).

There are two processes that are necessarily involved in plant range expansion: i) the dispersal of propagules beyond the current range limit, and ii) the establishment and growth of pioneer populations (Nathan et al. 2003). Both processes contain a strong hypothetical component which usually undetected by direct observation and hence is extremely difficult to measure in nature (Nathan et al. 2003; Nathan 2006; Simberloff 2009). Nevertheless, methods for differentiating the current and potential expanded distribution of species had received little consideration. Since the current distribution of many plant species that has the potential to expand their ranges may be much smaller than their maximum distributions (e.g., studies by Ward et al. 2009), robust methods are required for discriminating suitable habitat that is occupied and habitat that could potentially be occupied. The first necessary step is to distinguish "suitable" from "unsuitable" habitat in its current range limit, and recently two general approaches have been used for this purpose. Presence-only data and enviro-climatic variables can be used to fit predictive "niche-based models" of distribution by various methods (Elith et al. 2006). Nevertheless, presence-only modeling requires careful attention on how the data collected so that major spatial and detection biases may be reduced or even eliminated (Gu and Swihart 2004; Wintle et al. 2005; Araujo and Guisan 2006). The second step is to project the potentially "suitable" habitat outside of current range limit in its vicinity regardless of how the process of its dispersal.

Recently, Ecological Niche Modelings (ENMs) with its set of enviro-climatic variables are being used for the purposes, for instance, in the prediction of expansion biology, particularly to predict invasion risks (in the case of invasive species) and optimize control strategies (e.g.,
Bradley et al. 2010; Jimenez-valvarde 2011; Giljohann et al. 2011; Tulloch et al. 2014; Lecocq et al. 2016; Kramer et al. 2017). However, there are two key assumptions of ENMs that are often violated in expansion biology. Firstly, niche conservatism in ENMs is an assumption required for model transferability, whereby climate niches of the species being modeled from the native area are to be projected onto new geographical spaces to estimate the likelihood of successful expansions there (Barbet-Massin et al. 2018). In the context of expansion biology, niche conservatism differs remarkably from evolutionary niche conservatism (fundamental niche conserved over evolutionary time), since the question is to understand whether the species' realized niche is preserved over space, Nonetheless, the assumption of niche conservatism over space is not always conjoint, since the naturalized climatic niches of expansive species can differ from their native climatic niches (Medley et al. 2010; Early and Sax 2014; Parravicini et al. 2015). Secondly, up till the latest stage of expansion, the species is not yet at equilibrium with its environment (Gallien et al. 2012); therefore its climatic niche is likely underestimated. Despite the criticisms, the pivotal need for predictive models is such that ENMs are still often used in species range expansion studies.

Using the theoretical frameworks explained above, here we demonstrate the application of Ecological Niche Modelings (ENMs) to predict the distribution of current "suitable" niche for Selaginella zollingeriana Spring in Java Island and its potential "suitable" niche across the Indonesian archipelago based on enviro-climatic variables. Since the potential expansion would occur for decades, we incorporate the potential changes in future climate conditions through the implementation of projected future climate conditions using various scenarios. Therefore, we could gather information on the distribution of areas/regions where the species could potentially be dispersed and survived outside of recent-known distribution.

The choice of $S$. zollingeriana provides an excellent context of the study on modeling species expansion under future climate projection. According to Setyawan et al. (2013), this species is distributed mainly in the islands of Java and Bali, and found mostly on the cliff walls of headstone and tomb, or on the shaded cliff, or on the plastered roadside and dirt drainage ditch. The recorded altitude of species' presence is at 1150-1222 $\mathrm{m}$ asl. This species is capable of surviving and growing its colony among the biotic interactions between species in Java Island along with its climatic, physiographic, topographic, and edaphic conditions for the unrecorded periods of time. This has become a subject of interest for ecologist and botanist since the vast variety of enviro-climatic condition in Java Island more or less represents the enviro-climatic condition of Indonesia. Therefore, questions regarding whether there are other areas outside the island that are capable of supporting the survival of this species may arise. Then, an inquiry regarding how that suitability degree may change in conjunction with the possible changes in future climate conditions will also emerge. 


\section{MATERIALS AND METHODS}

\section{Study area}

Indonesia is an archipelagic country located in the southeast region of Asia. This country consists of about 17,508 islands wherein only 16,056 of its island names have been verified by the United Nations Group of Experts on Geographical Names (UNGEGN) in July 2017 (https://unstats.un.org/unsd/ungegn/). The geographic scope of this study includes the region of approximately 6 ${ }^{\circ} \mathrm{N}$ to $11^{\circ} \mathrm{S}$ latitude and $95^{\circ} \mathrm{E}$ to $141^{\circ} \mathrm{E}$ longitudes (Figure 1), covering about 1.9 million $\mathrm{km}^{2}$ of lands. The highest peak of Indonesia is Mt. Puncak Jaya at roughly 4,884 m asl located in Papua Island.

The climate in Indonesia is varied wherein it is mostly experiencing a tropical rainforest climate with some areas have tropical monsoon and tropical savanna. Nevertheless, oceanic climates and subtropical highland climates are also found in several high-altitude regions in this country, mostly between 1,500 and 3,500 meters above sea level. Regions that are above $3,500 \mathrm{~m}$ asl (mostly in Papua highlands) experiencing tundra climate and subpolar oceanic climates (Climate-data.org).

\section{Procedures}

\section{Presence Records}

For this study, authors collected the occurrence data of S. zollingeriana from two primary sources, i.e., field survey and the Global Biodiversity Information Facility (GBIF) database. Field survey aiming to obtain the primary presence records for the species was conducted in all provinces across Java Island between July 2007 and January 2014. The specimens found were identified using several references on Selaginella of the Malay Archipelago and adjacent regions (Alston 1934, 1935a,b, 1937, 1940; Wong 1982, 2010; Tsai and Shieh 1994; Li and Tan 2005; Chang et al. 2012; Zhang et al. 2013) to ensure the highconfidence level of species identification. The coordinate of each specimen was recorded using Garmin eTrax GPS series. Subsequent to confirming the species taxonomy, twenty-four coordinate records were used in this study. None of the error-correction methods were conducted since we ensured that the level of telemetry error of modern GPS has little effect on the accuracy of the model (Montgomery et al. 2011).

The second source of presence records was from the GBIF database (GBIF 2016). All of the records acquired from GBIF were carefully verified, and errors that may occur were corrected using Google Earth software (Google Earth Pro 2017). Records with no latitudinal and longitudinal information were geo-referenced using Biogeomancer Workbench (http: //www.biogeomancer.org) guided by locality descriptions on each datum, and then data records that do not have specific locality description and cannot be geo-referenced were removed (Guralnick et al. 2006). We comprehend the possibility of strong geographic biases that often contained in such open database wherein its data were collected from opportunistic observation and/or historical collection of records (Stolar and Nielsen 2015). Moreover, the biases mentioned above proved to have strong effects on modeling prediction ability and later interpretation (Kramer-Schadt et al. 2013; Fourcade et al. 2014). Therefore, we conducted two out of five sampling bias correction methods proposed by Fourcade et al. (2014). Subsequently, after we identified the type of sampling data bias contained in the sampling data used for this study, we conducted two out of five sampling bias correction methods, i.e., (i) Spatial filtering, performed by creating a grid of $2 \mathrm{~km} \times 2 \mathrm{~km}$ cell size and randomly select only one point of occurrence per grid cell. Nevertheless, it should be noted that the size of this grid is not the representation of approximate species' dispersal capabilities, but rather as a result of modifying the $10-\mathrm{km}$ radius rule of spatial filtering proposed by Kramer-Schadt et al. (2013) and Boria et al. (2014). The grid creation and point selection were conducted using QuantumGIS software ver. 3.2.0 (QGIS Development Team 2017). (ii) Bias file, produced using Gaussian kernel density map approach and then included it into MaxEnt modeling process through the setting option (Dudik et al. 2005; Elith et al. 2011; Phillips et al. 2017). The remaining six presence records that considered suitable were combined with the data from field study; therefore, a total of 30 points were used in this study.

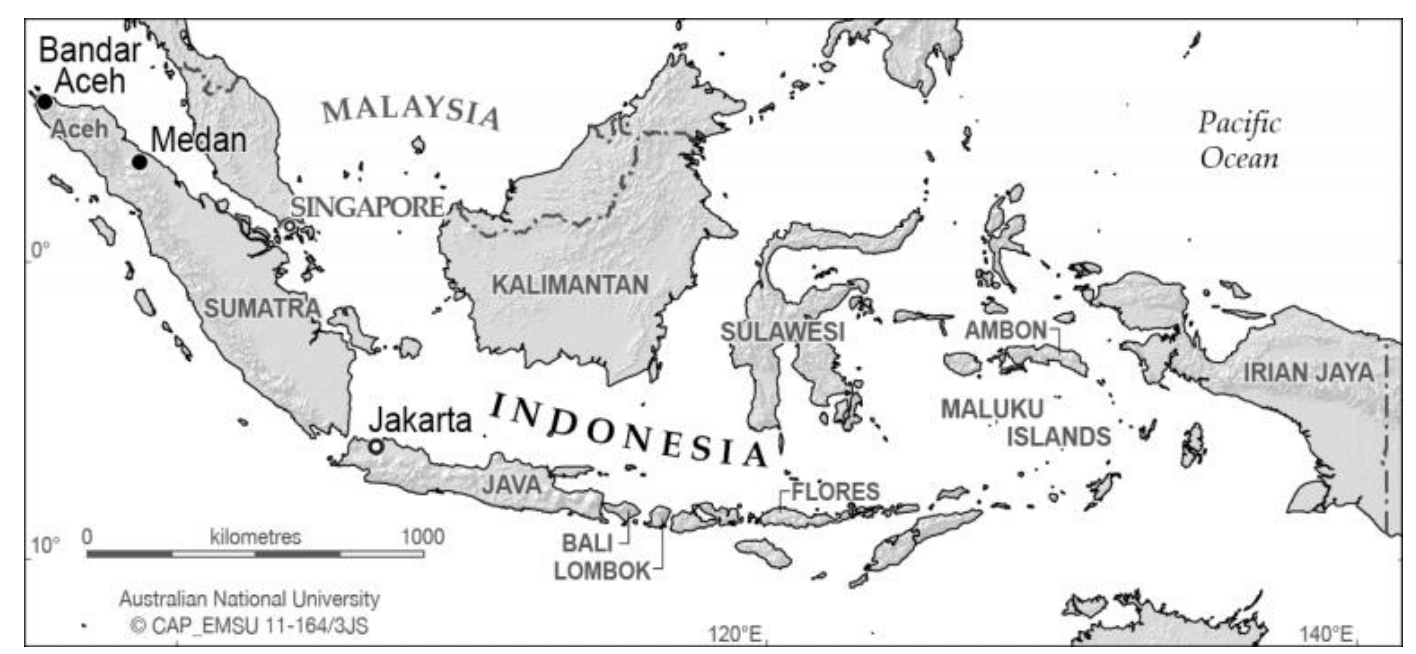

Figure 1. Area of study, Indonesia. (Base map: Google Physical Maps 2014) 


\section{Enviro-climatic variables}

Based on the previous screening process on the variables that are expected to have direct effect on the species distribution (e.g., Soria-auza 2009; Hu et al. 2015; Mod et al. 2016; Setyawan et al. 2017; Velazco et al. 2017; Setyawan et al. 2020a; Setyawan et al. 2020b), we collected 19 bioclimatic variables, three edaphic variables, and one altitudinal variable. Bioclimatic ver. 2.0 and altitude layers were collected from WorldClim Bioclimatic datasets website (www.worldclim.org). Global Soil $\mathrm{pH}$ $(\mathrm{SpH})$ and soil organic carbon (SOC) datasets were collected from the International Center for Tropical Agriculture (https://dataverse.harvard.edu). Soil type dataset was collected from freely available Food and Agriculture Organization of the UN (FAO-UN) website (http://www.fao.org). Due to the limited availability, other variables considered as important and directly affecting species' occurrence (i.e., biotic interactions, human disturbance, possible future land use/cover change, and species' dispersal capability) were not included.

It has been broadly acknowledged that the high correlation among bioclimatic layers will limit interpretation of the variable's contributions; thus, hindrance the correct inferences on the contribution of each variable for being made. Therefore, by using SDM toolbox Ver. 2.0 (Brown 2014), we performed autocorrelation calculation and automatically omitted the bioclimatic variables yielded correlation values above 0.85 (Spearman's rho coefficient) in the pairwise crosscorrelation matrix of each dataset (intra-dataset correlations) (Bedia et al. 2013). The remaining nine bioclimatic variables (i.e., bio_1, bio_2, bio_3, bio_4, bio_12, bio_13, bio_15, bio_17, and bio_19) were then compiled with three edaphic variables (FAO types of soil, Soil pH and Soil Organic Carbon), plus one environmental variable (i.e., altitude) (Table 1).

\section{Future scenarios}

The possible expansion of S. zollingeriana population may take decades to occur, and throughout that time, the bioclimatic conditions are highly possible to change. Accordingly, the distribution of suitable niches for $S$. zollingeriana to disperse may also change dynamically. To model this dynamic change of niche distribution, we used future bioclimatic scenarios acquired from the CGIAR Research Program on Climate Change, Agriculture, and Food Security website (www.ccafs-climate.org). Following the suggestion from Collins et al. (2011), we selected the HadGEM2-CC (Hadley Global Environment Model-2 Carbon Cycle) global circulation model, which was developed by the Hadley Center United Kingdom, to be used in this study. Projection of future climate conditions is divided into several scenarios representing different greenhouse gas (GHG) scenarios. These scenarios are represented by Representative Carbon Pathways (RCP), namely RCP 2.6, RCP 4.5, RCP 6.0, and RCP 8.5, and projected for the years 2030, 2050, and 2080 (averaged two decades up and down the year). RCP 2.6 represents the most optimistic projection which assumes that global GHG will increase slowly to reach its peak at $3.1 \mathrm{~W} / \mathrm{m}^{2}$ between
2010-2020, and then with the help of new technologies and climate policies, GHG will decline substantially thereafter to $2.6 \mathrm{~W} / \mathrm{m}^{2}$ by the year 2100 (van Vuuren et al. 2007; Moss et al. 2010). RCP 4.5 and RCP 6.0 are moderate predictions wherein the emission will stabilize at $4.5 \mathrm{~W} / \mathrm{m}^{2}$ and $6.0 \mathrm{~W} / \mathrm{m}^{2}$ respectively (Clarke et al. 2007). The most pessimistic projection is the RCP 8.5 projecting the emissions level will continue to increase throughout the century, reaching around $8.5 \mathrm{~W} / \mathrm{m}^{2}$ as the highest level by the end of the century (Riahi et al. 2011). Assuming the most optimistic and the most pessimistic for future climate conditions and by considering the slow expansion rate of the species, we selected the RCP 2.6 and RCP 8.5 for the years 2030, 2050 and 2080 to be used as variables to model future suitable niche distribution for the species. Due to the limited availability of future projections, the other environmental variables (Soil pH, Soil Organic Carbon) remained unchanged. Furthermore, the same altitude layer was used since this variable is a static variable that remains unchanged with time.

Due to its simplified physics and thermodynamics processes, coarse spatial resolution, and numerical schemes, and incomplete knowledge of climate systems, such climate model contains errors (biases) (RamirezVillegas et al. 2013). Therefore, the implementation of bias correction is necessary. Using correction data provided by CGIAR-CCAFS, we implemented three different calibration approaches: (i) Change Factor (CF): in this approach, the raw GCM outputs current values are subtracted from the future simulated values, resulting in "climate anomalies" which are then added to the observational dataset (Tabor and Williams 2010), (ii) Bias Correction, this approach revise the projected raw GCM output using the differences in the mean and variability between observations and GCM, in a reference period (Hawkins et al. 2013), (iii) Quantile Mapping (QM), this approach removes the systematic bias in the GCM simulations and accounts the biases in all statistical moments, however, like all statistical downscaling approaches, it is assumed that biases relative to historical observations will be constant in the projection period (Thrasher et al. 2012).

Table 1. Environmental variables used to build the models

\begin{tabular}{lll}
\hline Code & Name & Unit \\
\hline Alt & Altitude & $\mathrm{m}$ asl \\
bio_1 & Annual Mean Temperature & ${ }^{\circ} \mathrm{C} \times 10$ \\
bio_2 & Mean Diurnal Range & ${ }^{\circ} \mathrm{C} \times 10$ \\
bio_3 & Isothermality & $\times 100$ \\
bio_4 & Temperature Seasonality & $\mathrm{SD} \times 100$ \\
bio_12 & Annual Precipitation & $\mathrm{mm}$ \\
bio_13 & Precipitation of Wettest Month & $\mathrm{mm}$ \\
bio_15 & Precipitation Seasonality & $\mathrm{mm}$ \\
& (Coefficient of Variation) & \\
bio_17 & Precipitation of Driest Quarter & $\mathrm{mm}$ \\
bio_19 & Precipitation of Coldest Quarter & $\mathrm{mm}$ \\
Soil_types & FAO soil classification & \\
soil_carbon & Soil Organic Carbon & \\
soil_ph & Soil pH & \\
\hline
\end{tabular}




\section{Modeling}

For this study, we used freely available MaxEnt software ver. 3.4.1 (Philips et al. 2017) acquired from the American Museum of Natural History (https://biodiversityinformatics.amnh.org). Several studies have presented the importance of parameter configuration in MaxEnt modeling, rather than using default parameter setting (e.g., Warren and Seifert 2011; Merow et al. 2013; Yackulic et al. 2013; Halvorsen et al. 2015), especially when the number of presence data is small (Merow et al. 2013; van Proosdij et al. 2016; Pearson et al. 2007; Morales et al. 2017). Therefore, we built this model after reviewing and repeatedly testing the various combinations of parameter settings so that the model, which was built using small presence data, would yield more reliable results.

The following parameter settings were adjusted based on the species-specific considerations and reflecting our intended a priori assumptions (Peterson et al. 2011; Araujo and Peterson 2012; Merow et al. 2013). Maximum iterations were set to 5,000 for each run to allow the model to have adequate time for converging along with the Convergence threshold was set to $1 \times 10^{-6}$. Each trial was replicated ten times (the averaged value is the one used as the result) using "Bootstrap" as the replicated run type with $20 \%$ random test percentage (Merow et al. 2013). The "Bootstrap" used in this study means that for each run a random of $20 \%$ of presence data would be sampled as test data. Nevertheless, opposite to subsampling, the sampled data is replaced so that the point may be included in test data more than once. To avoid over-fitting and to assume that the species respond directly to the predictors (vs. to correlated factors), we decided to "smooth" the model by choosing only hinge features (Merow et al. 2013). Along with the default prevalence value of 0.5 , we tested several "multiplier regularization (mr)" $(1,2$, and 3$)$ and then selected the best mr value based on the calculated TSS and pAUC value, visual evaluation, and jackknife test evaluation (Elith et al. 2006; Merrow et al. 2013; Radosavljevic and Anderson 2013). Considering the aim of this study, which is to model species expansion and to accommodate the small size of presence data, we chose the best multiplier regularization value of 2.00. Since one of the aims of the study is to find the distribution of similar environmental conditions across the country from where the species currently maintain populations (in this case Java Island), we sampled background points at the maximum number of 10,000 from this island only. We used the "projection" feature to extrapolate the model into different climate projections and different islands across the country (van der Wall et al. 2009).

\section{Data analysis}

One of the main outputs of Maxent is an ASCII grid representing the distribution of potentially suitable niches of the species across the study area. Using the "logistic" output format, representation of probabilities in the grid is linearly scaled between 0 (lowest) to 1 (highest) probability (Philips and Dudik 2008). To conveniently quantify and compare the predictive grids, we applied binary transformation by categorized the values into two categories (i.e., suitable and unsuitable) using the selected threshold rule. Selecting threshold can be deceptive since one must consider the relative importance differences of commission and omission errors and must emphasize one after the other based on the study objectives. (Phillips and Dudik 2008; Nenzen and Araujo 2011; Bean et al. 2012; Syfert et al. 2013). Norris (2014) and Liu et al. (2016) have explained comprehensively the selection process of a threshold for modeling with presence-only data. Acknowledging the necessity to reduce omission error in the case of modeling species having a possibility to expand in the future, "minimum training presence" was selected as the threshold rule applied in the model. The potentially suitable niche was then reclassified into three classes: low suitability (25-50\% probability of occurrence), medium suitability, (51-75\% probability of occurrence), and high suitability ( $>75 \%$ probability of occurrence), by using the "natural breaks (Jenks) classification method in Reclassify Analysis of ArcMap ver. 10.3 (ESRI 2011).

We also performed the jackknife test to calculate the variables' relative contribution to the model and quantify the degree to which these variables affect the prediction. Jackknife test shows which variable appears to have the most information that is not present in the other variables and which variable has the most useful information by itself (Phillips and Dudik 2008). The predictive grids, which by default are in ASCII format, were further analyzed using QuantumGIS software ver. 3.2.0 (QGIS Development Team 2017).

The area under the receiver operating characteristic (ROC) Curve (AUC) value, which was produced by MaxEnt and frequently used to evaluate performance model, has been proved to provide limited useful information in the process of evaluating model performance (Lobo et al. 2008; Bahn and McGill 2013; and Aguirre-Gutiérrez et al. 2013). Therefore, several studies used different statistical approaches. Allouche et al. (2006) proposed True Skill Statistic (TSS) as a post-hoc evaluation for the MaxEnt model built by presence-only data and has been used frequently since it was introduced. True Skill Statistic (TSS) (also known as the Youden index) calculation is derived by calculating the summary of sensitivity and specificity minus one (Youden 1950). This approach has been proven to be free from the dependence of prevalence while still keeping all the advantages of kappa which was widely used as an evaluation tool. Cohen's Kappa has been widely used due to its simplicity, the fact that both commission and omission errors are accounted for in one parameter, and its relative tolerance to zero values in the confusion matrix (Manel et al. 2002). However, several studies have criticized the kappa statistic for being inherently dependent on prevalence and claimed that this dependency introduces bias and statistical artifacts to estimates of accuracy (Cicchetti and Feinstein 1990; Byrt et al. 1993; Lantz and Nebenzahl 1996). Consequently, we assume that the use of TSS is more suitable for this study. 


\section{RESULTS AND DISCUSSION}

The current distribution of potentially suitable niche of $\mathrm{S}$. zollingeriana in Java Island

The model built using 30 presence data along with twelve enviro-climatic variables depicts the spatial distribution of potentially suitable niche for $S$. zollingeriana across the Java Island wherein this species is suggested endemically maintaining its population. Subsequent to categorizing the output into binary categories (suitable vs. unsuitable), the predicted suitable habitat were then reclassified into three classes by using the "natural breaks (Jenks) classification method i.e., low suitability (25-50\% probability of occurrence), medium suitability (51-75\% probability of occurrence), and high suitability ( $>75 \%$ probability of occurrence) to allow us to project the distribution of potentially suitable niche in different suitable level under different climate condition.
The model predicted roughly $17.22 \%\left(22,095 \mathrm{~km}^{2}\right)$ of the Java Island area is potentially suitable niche for $S$. zollingeriana. This number consisted of $10.93 \%(14,028$ $\left.\mathrm{km}^{2}\right), 4.75 \%\left(6,097 \mathrm{~km}^{2}\right)$, and $1.54 \%\left(1,970 \mathrm{~km}^{2}\right)$ of low, medium, and high suitability areas, respectively (Figure 2).

The potentially suitable niche is distributed mainly in the mountainous areas of the island. Nevertheless, the surrounding lowland areas are also predicted to be potentially suitable although they have low suitability category. Altitudinally, the low probability areas were mainly distributed in lower-end up to higher areas at the altitude of between 300 and $2100 \mathrm{~m}$ asl, whereas medium probability areas were mainly distributed at a higher altitude of between 1300 and $2800 \mathrm{~m}$ asl. Moreover, the high probability areas were also mainly distributed in the highland region at the altitude of 1800 to $3600 \mathrm{~m}$ asl (Figure 3).

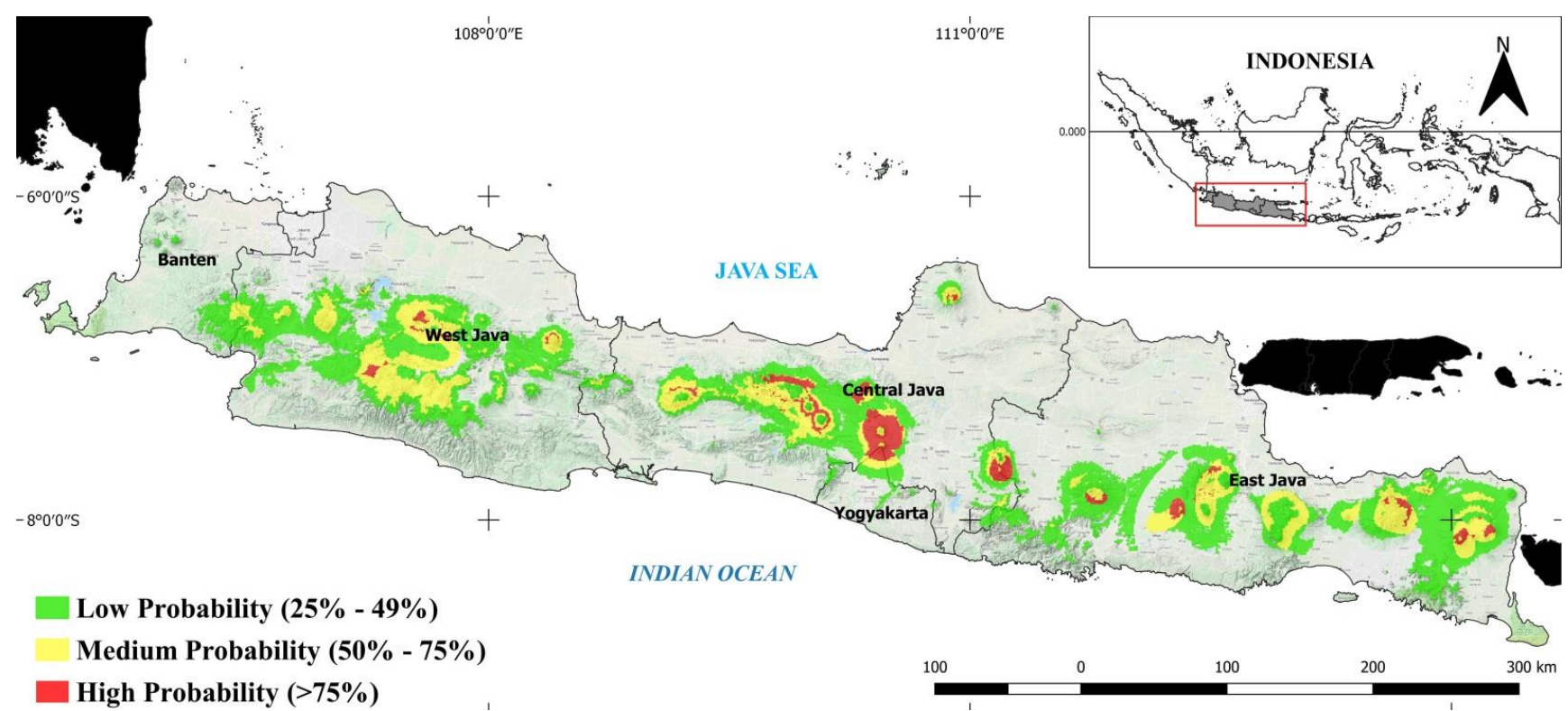

Figure 2. Predicted distribution of potentially suitable niche for S. zollingeriana in Java Island under current climate conditions. (Base map: Google Physical Maps 2014)

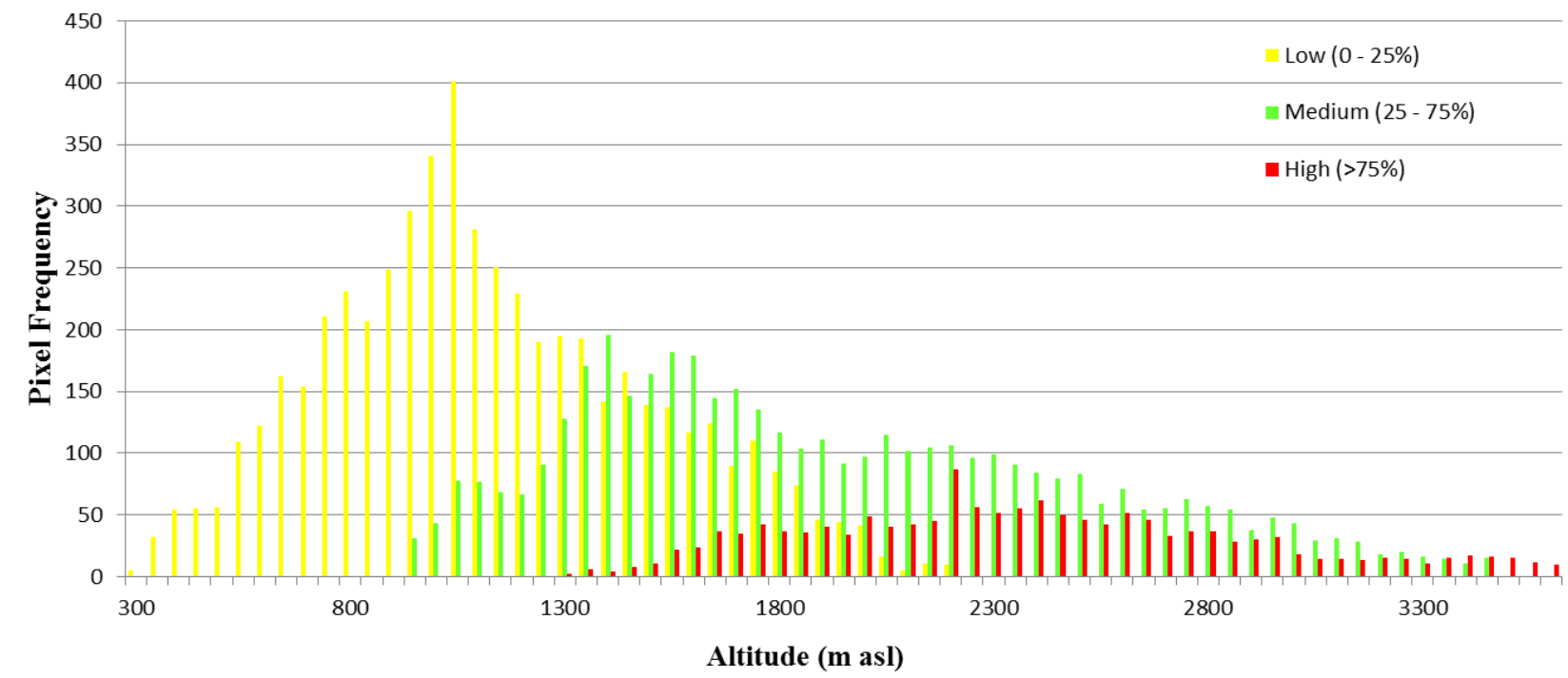

Figure 3. Predicted altitudinal distribution of potentially suitable niche of S. zollingeriana in Java Island under current climate condition 


\section{Model evaluation}

Prior to interpreting the results further or using them in any procedure, a post-hoc model evaluation is commonly performed to assess the relative predicting performance and statistical significance of the model (Peterson et al. 2011). The AUC values may have been accentuated to be misleading and do not provide a strong reflection of model accuracy; however, we retrieved the AUC value of 0.954 to, by some degrees, illustrate that the model built in this study performed better than any model built using set of random predictors and to illustrates the discrimination ability of the model (Lobo et al. 2008; Peterson et al. 2008; Jimenez-Valverde 2012, 2014; Fourcade et al. 2014, 2017). Additionally, the True Skill Statistic (TSS) value, which has been proposed as an alternative metric of evaluation (e.g., Allouche et al. 2006; Hijmans 2012; Phillips and Elith 2010), was retrieved by calculating the summary of sensitivity and specificity minus one. The TSS value of 0.789 means that the model has a better ability at discerning the presence and background points given the threshold supplied than any random model. Therefore, the value gives the impression that model built in this study have a good degree of agreement, good predictive capacity, and also can be interpreted as evidence for the real ecological phenomenon, based on environmental variables used, rather than statistical artifacts (Allouche et al. 2006; Li and Guo 2013).

The dominant environmental variables and their significance on the probability of species' presence

According to the relative contributions of environmental variables generated by Maxent (Table 2), the top three variables that significantly affect the distribution of $S$. zollingeriana were as follows: (i) Altitude (Alt), (ii) Annual mean temperature (Bio_1), and (iii) Soil types (Soil_types). The combination of these three variables contributed to a total of $88.5 \%$ to the MaxEnt model, whereas the rest of the variables contributed each less than 5\%. Additionally, we retrieved the alternative estimation of variable importance to the models via the jackknife test (Figure 4). The results depicted that the highest environmental variable with the highest training gain, when used in isolation, is annual mean temperature (bio_1), which means that this single variable appeared to have the most useful information by itself and proved to have the highest permutation importance value of $50.4 \%$. Moreover, the environmental variable that decreases the gain the most when it is omitted is soil types (Soil_types), which therefore appears to have the most information that is not present in the other variables (Phillips and Dudik 2008).

Table 2. Percentage of variable contribution to the final model

\begin{tabular}{llc}
\hline Variables & \multicolumn{1}{c}{ Description } & $\begin{array}{c}\text { Contribution } \\
(\boldsymbol{\%})\end{array}$ \\
\hline Alt & Altitude & 35.5 \\
bio_1 & Annual Mean Temperature & 27.2 \\
Soil_types & FAO soil classification & 25.8 \\
bio_3 & Ishotermality & 3.9 \\
bio_12 & Annual Precipitation & 3.1 \\
bio_13 & Precipitation of Wettest Month & 1.9 \\
bio_19 & Precipitation of Coldest Quarter & 1 \\
soil_carbon & Soil Organic Carbon & 0.8 \\
bio_15 & Precipitation Seasonality & 0.5 \\
& (Coefficient of Variation) & 0.3 \\
bio_12 & Annual Precipitation & 0 \\
bio_4 & Temperature Seasonality & 0 \\
bio_17 & Precipitation of Driest Quarter & 0 \\
soil_ph & Soil pH & \\
\hline
\end{tabular}

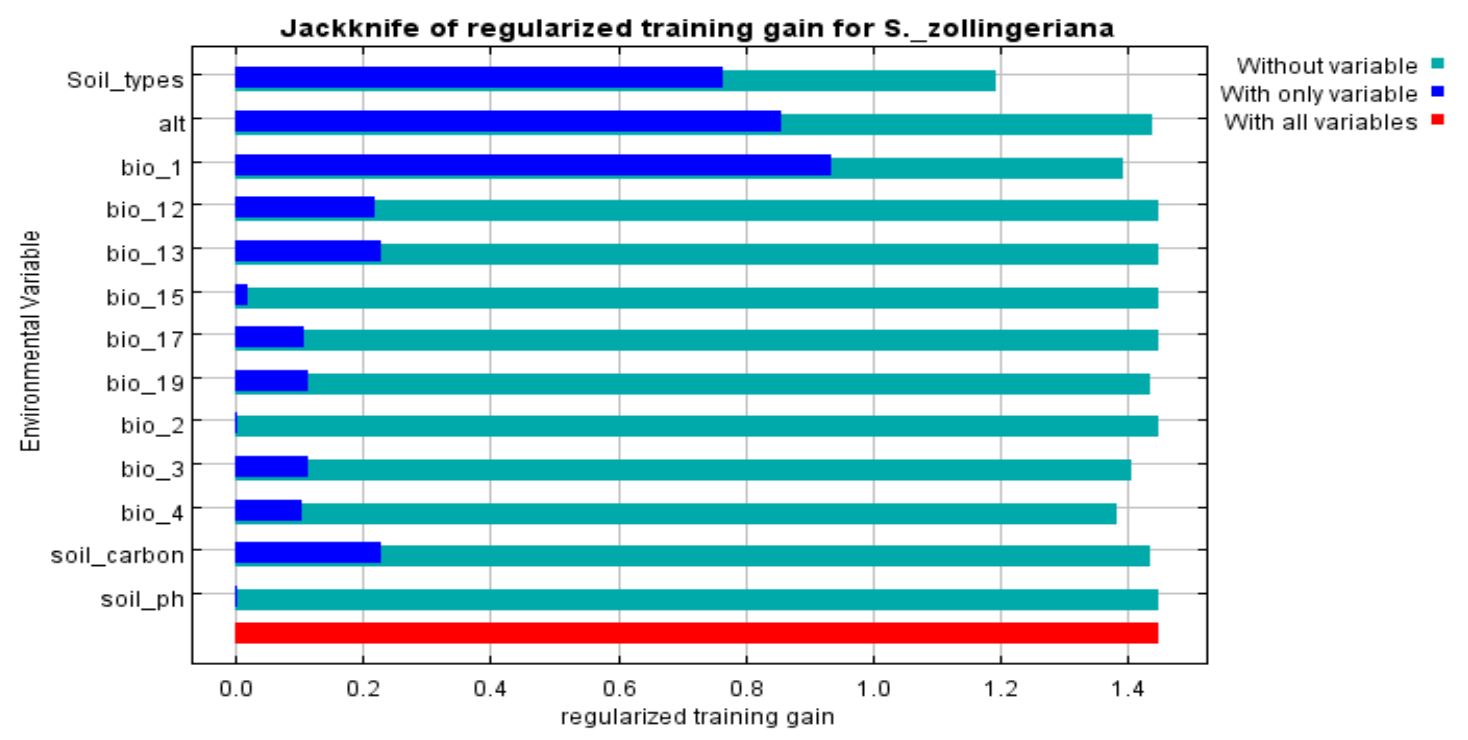

Figure 4. Results of jackknife test of relative importance of predictor variables for the model 
The response curves were presented to show how each of the dominant environmental variables affects the MaxEnt prediction. These plots of curves reflect the dependence of predicted suitability both on the selected variable and on dependencies induced by the correlation between the selected variable and other variables (Phillips et al. 2008). The response curve between the presence probability of $S$. zollingeriana and altitude (alt) (Figure 5a) shows that the probability of species' presence is increasing gradually along with the increase of altitude. The presence probabilities are higher than $50 \%$ at the altitude of about $800 \mathrm{~m}$ asl and then reached their peak (probability 70\%) at about $1,100 \mathrm{~m}$ asl before gradually decreased to $60 \%$ probability at the altitude of higher than $1,500 \mathrm{~m}$ asl. The next response curve (Figure $5 \mathrm{~b}$ ) shows the optimum annual mean temperature (bio_1) for this species' niche ranged between $12^{\circ} \mathrm{C}$ and $21^{\circ} \mathrm{C}$ before the probability presence gradually declined at the mean temperature above $22^{\circ} \mathrm{C}$. Furthermore, the third most dominant variable affecting species niche is soil types. The figure shows that there are three types of soil having the highest probability of species' presence, i.e., Be: Eutric Cambisols (code: 4475), Lo: Orthic Luvisols (code: 4535), Nd: Dystric Nitosols (code: 4543). These types of soils are inherently fertile of the tropical soils because of their high nutrient content and deep, permeable structure; thus mostly exploited for agriculture purposes (FAO 2019) (Figure 5c).

\section{Possible species expansion in the future based on potential niche distribution}

The model which was built for Java Island was then projected into future climatic condition to a wider extent across Indonesia to simulate the possible niche distribution in other islands of the country (Figure 6). The lowest $S$. zollingeriana presence threshold to predict and map the suitable niche was set at the "minimum training presence" threshold (probability presence $=0.23$ ). The presence probability above the threshold was then reclassified into three probability classes (see method). Overall, the model predicted the possibility of species expansion into the other four big islands (i.e., Sumatera, Borneo, Sulawesi, and Papua). Nevertheless, the distribution of the potentially suitable niche is non-uniform wherein in some islands the niche distribution is wider while in the others distribution is narrower. The possible explanation for this phenomenon is due to the inherent differences in environmental conditions among the big islands. Following the result of variable contribution and jackknife calculation, discrepancies in altitude, temperature, and Isothermality conditions are predicted to influence the distribution pattern of suitable niches in these islands significantly.

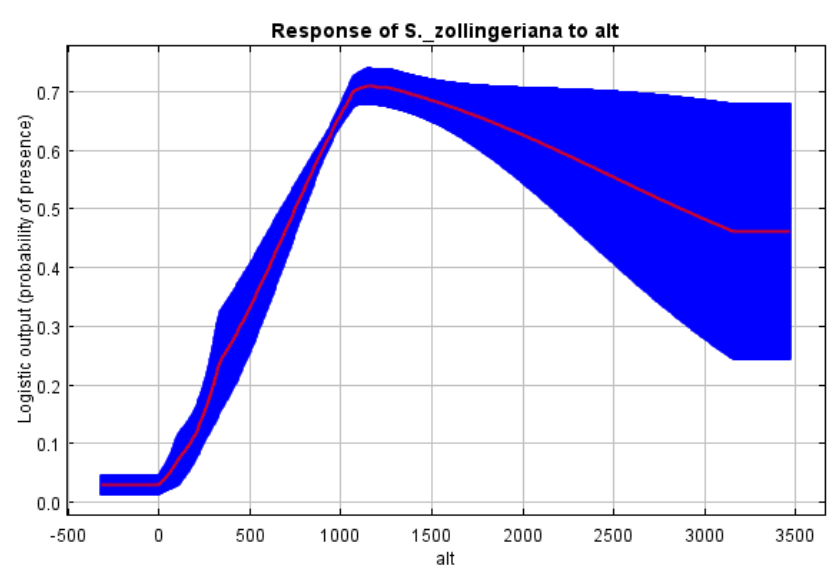

A

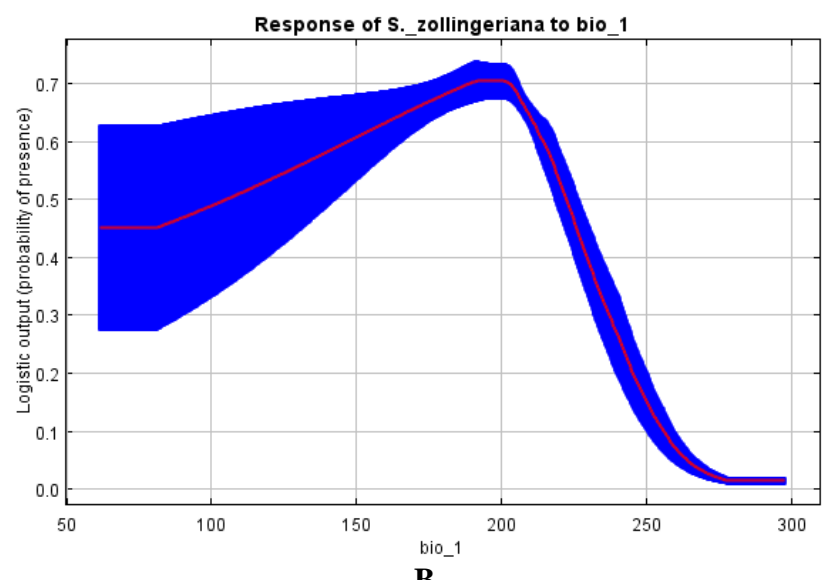

B

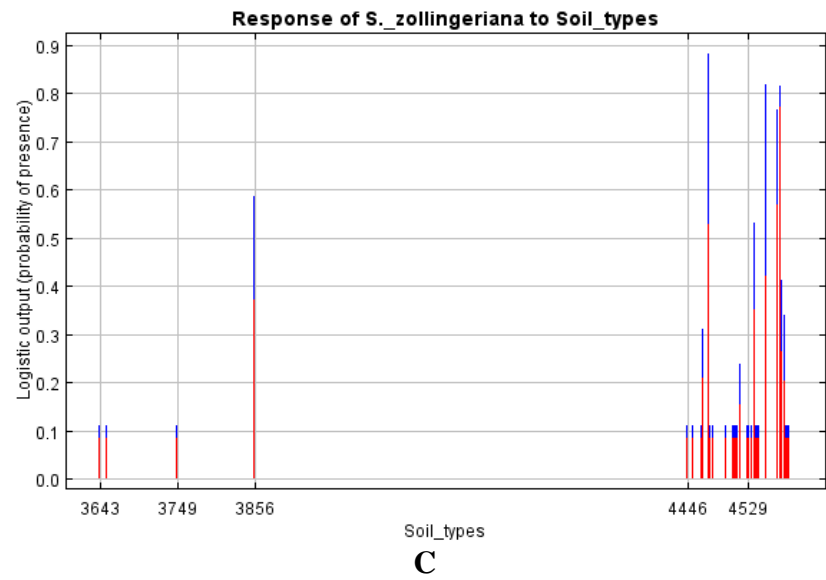

Figure 5. Response curves from MaxEnt for the most important variables for the species distribution model: A. Altitude; B. Annual mean temperature (in ${ }^{0} \mathrm{C}^{*} 10$ ); C. FAO soil types classification. The curves show the mean response of the 10 replicate MaxEnt runs (red) and the mean +/- one standard deviation (blue, two shades for categorical variables). 


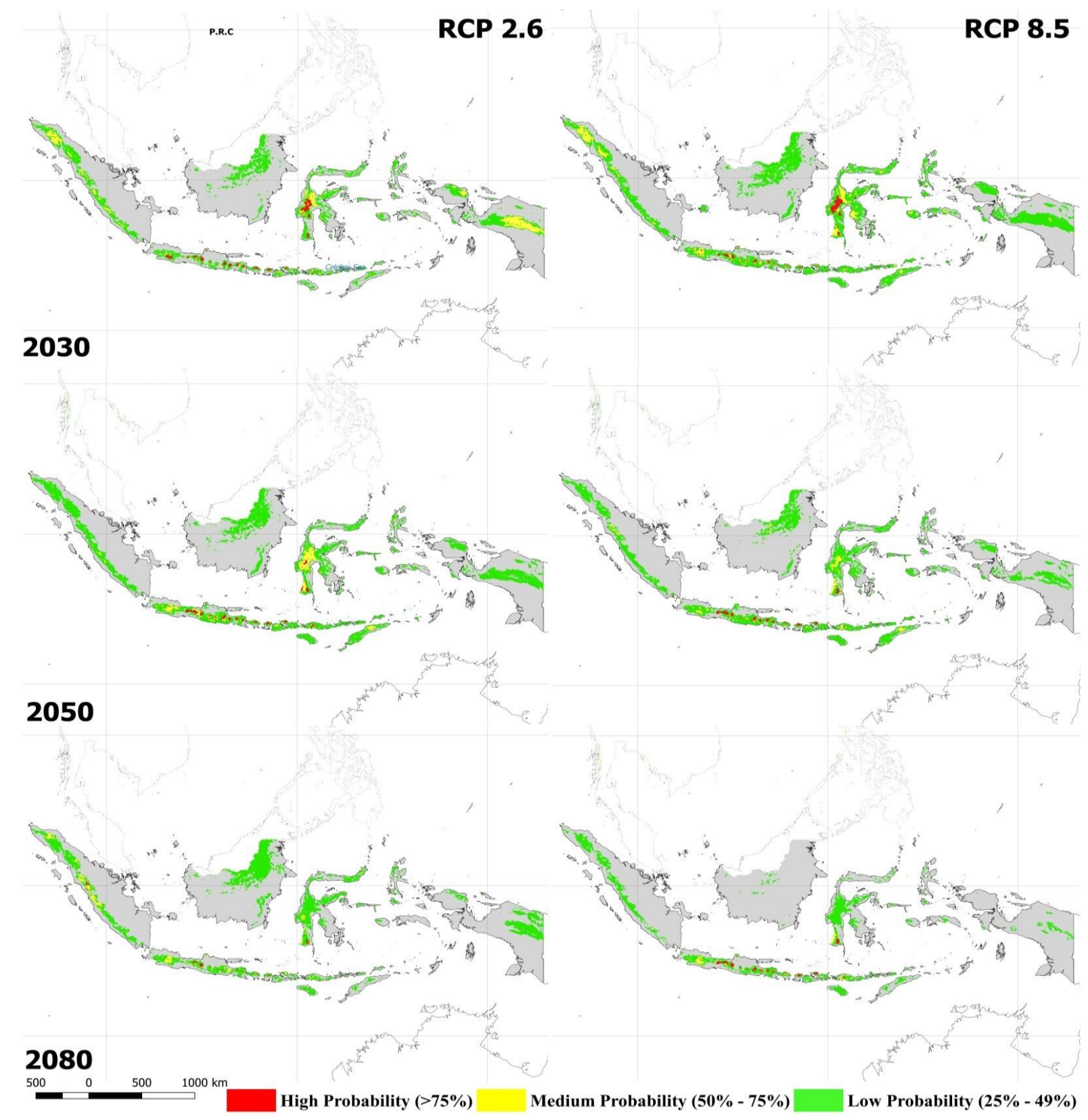

Figure 6. Predicted distribution of potentially suitable niche for S. zollingeriana across Indonesia under two different future climate scenarios

Considering the pace needed for the species to disperse, the model was not projected into current climate condition but to the future condition as early as 2030 under two different climate scenarios. In general, using the most optimistic GHG emission scenarios produced a wider distribution of possible suitable niches than the more pessimistic scenario that produces a narrower and limited distribution of suitable niches (RCP 8.5). Across the time period to the further future, all of the scenarios projected a declining trend of the availability of suitable niche wherein from 2030 to 2080 the modeled niche declined about 58\% and 59\% at RCP 2.6 and RCP 8.5, respectively (Table 3 ). In all of the scenarios, lower probability has a more dispersed distribution than higher probabilities accounted about two-third of suitable niches are categorized as having a low probability (25\%-50\%). We then extracted the altitudinal value of the predicted suitable habitat from all scenarios in the attempt of investigating whether there are discrepancies in the altitudinal distribution among the scenarios. Across the periods of time, our models showed that the niche is projected to marginally shifted to higher altitudes. Even though the shifting is relatively small, the figures still represent the changes in climatic variability that may affect the future distribution of the species. From the current distribution to the year 2080 minimum altitudinal distribution shifted higher from about $300 \mathrm{~m}$ asl to around $511 \mathrm{~m}$ asl. The maximum altitudinal distribution was also projected to become higher from approximately $3600 \mathrm{~m}$ asl to about $3786 \mathrm{~m}$ asl, whereas the medial also slightly become higher by about $250 \mathrm{~m}$ (Figure 7). 
Table 3. The dynamics of potentially suitable niche for S. zollingeriana across Indonesia under two future climate scenarios in different periods of time

\begin{tabular}{lccccc}
\hline \multirow{2}{*}{ Year } & \multirow{2}{*}{ RCP Projection } & \multicolumn{3}{c}{ Area $\times \mathbf{~ 1 0}^{\mathbf{3}} \mathbf{k m}^{\mathbf{2}}$} \\
\cline { 3 - 6 } & & Low & Medium & High & Total \\
\hline 2030 & RCP 2.6 & 343 & 92.6 & 32.0 & 467 \\
& RCP 8.5 & 308 & 80.6 & 28.3 & 417 \\
2050 & RCP 2.6 & 299 & 67.2 & 24.2 & 391 \\
& RCP 8.5 & 243 & 56.5 & 19.0 & 319 \\
& RCP 2.6 & 209 & 53.5 & 12.7 & 275 \\
& RCP 8.5 & 190 & 49.7 & 9.1 & 249 \\
\hline
\end{tabular}

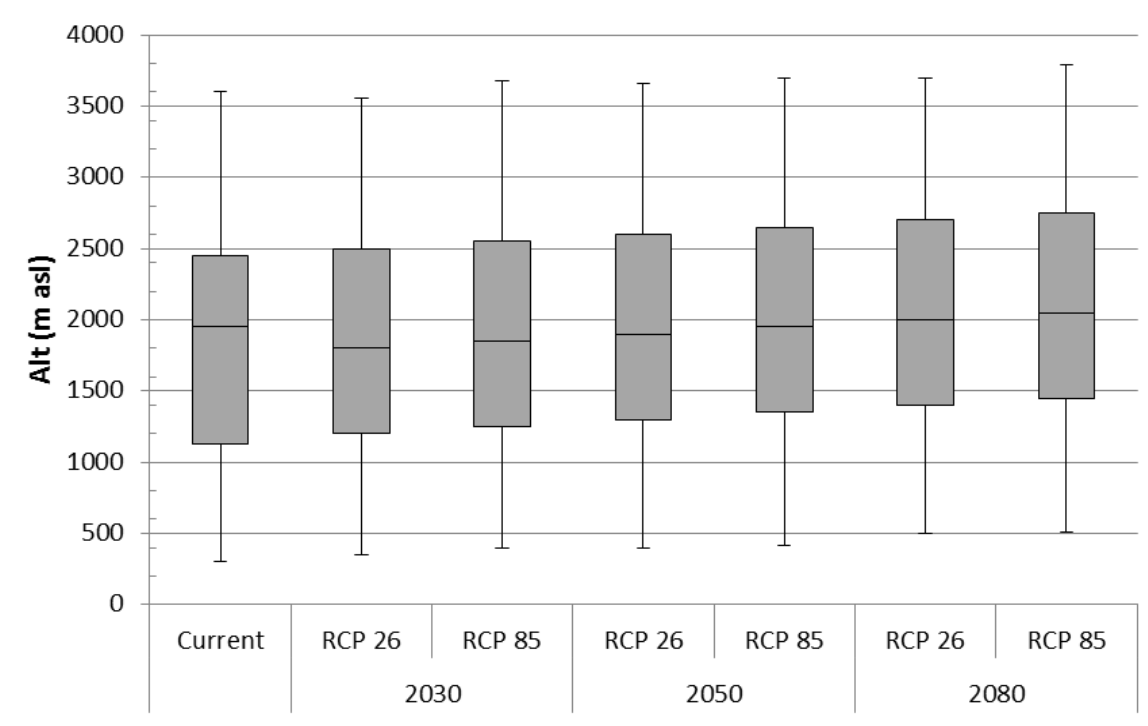

Figure 7. Predicted changes in the altitudinal distribution of potentially suitable niches under current and future climate projections. The box plots present median, lower quartile, upper quartile, maximum and minimum observations. Altitude is measured in $\mathrm{m}$ asl. (meter above sea level)

\section{Discussion}

This study presents a primary attempt to model the potential range expansion of $S$. zollingeriana by every possible means of species' proliferation, spread, and transportation while under the presumption of its range expansion will be greatly affected by differences in future climate condition. Across Java Island, it has been predicted that about $17.22 \%(22,095 \mathrm{~km} 2)$ of its area is suitable for the species based on the variables induced. Moreover, the model predicted the niche distribution of the species in its native island (Java) would be driven by the altitude level, the annual mean temperature, and its isothermality. Geographical variable, such as altitude, often connotes atmospheric pressure, local precipitation and temperature features (Austin 2002; Körner 2007); thus expected to affect greatly on determining the suitability of species in a certain niche. According to literature, Selaginella is a herbaceous plant that will likely grow in the moist or rather wet region. Therefore, elevation and temperature codependency affecting humidity plays an important role in the cause of species' survival. Isothermality (bio_3) is defined as the quantification of how large the diurnal temperature range oscillates with annual temperature oscillations (O'Donnell and Ignizio 2012). Previous studies (e.g., Jagels 1970, Eickmeier 1986) confirmed the importance of temperature and its stability in ensuring the survival of genus Selaginella.

The niche of S. zollingeriana in Java Island is predicted to be distributed widely but fragmented mainly to occur only in the highland areas at above $500 \mathrm{~m}$ asl. Discrepancies in local environmental conditions connoted by altitude (i.e., temperature and humidity) are to be expected as the cause of little to none suitable niche found in the lowland areas. Due to the adiabatic nature of the Earth's atmosphere, the denser air in the lowland has a greater heat absorption capacity than the thinner air in the highland areas. Therefore, the mean temperature in highland is expected to be lower than that of lowland areas. Temperature, as the second most dominant variable, allegedly affects both the photosynthetic capability and preservation of photosynthetic apparatus of Selaginella species (Jagels 1970, Eickmeier 1986). The negative correlation between temperature and the probability of species' presence (Figure 5c) illustrates the unsuitability of warmer temperature in lowland areas affecting species survival. For instance, Soni et al. (2012) in their study stated that Selaginella bryopteris show a very poor mechanism for its stomatal regulation in response to high 
temperature, which also affects its photosynthesis capability. Moreover, in regards to the effect of changes in precipitation level, studies conducted by Deeba et al. (2009) and Pandey et al. (2010) demonstrated drastic inhibition in net photosynthesis and maximal photochemical efficiency when Selaginella bryopteris induced with dehydration stress. Desiccation on this Selaginella species can also cause enhanced production of reactive oxygen species (ROS) and increased lipid peroxidation. In consequence, the increasing level of mean temperature and the decreasing level of precipitation is the most important compounding factor in determining the sustainability of Selaginella's habitat in the future.

Those allegations are aligned with the results of the predicted distribution of potentially suitable niches under future climate conditions across the Indonesian archipelago. Projected future climate condition in Indonesia has been predicted will significantly disturb the distribution of potentially suitable niche of $S$. zollingeriana, altering its geographical distribution pattern. Under the lowest GHG emission projection (RCP 2.6), wherein radiative forcing will gradually rise before it stabilizes at $2.6 \mathrm{~W} / \mathrm{m}^{2}$ by 2100 , the annual mean temperature will rise to about $0.4-0.7^{0} \mathrm{C}$ in all areas of Indonesia (Meinshausen et al. 2011; IPCC 2014). While under the worst emission scenario (RCP 8.5), the annual temperature will rise to $1.7^{0} \mathrm{C}$. This condition is predicted to decrease the probability of regional niche to support the existence of $S$. zollingeriana. From the total of $467 \times 10^{3} \mathrm{~km}^{2}$ predicted suitable niche in 2030 under RCP 2.6, the predicted suitable niche would decrease significantly to around half the number $\left(249 \times 10^{3} \mathrm{~km}^{2}\right)$. Global warming is also projected to favor range shifts, especially upward migrations, for many species for which temperatures are the main limiting factor of their geographic distribution (Parmesan et al. 1999; Saxe et al. 2001; Bale et al. 2002; Harvell et al. 2002). Distributional shift assessment using the extracted altitudinal value of the predicted suitable niche under current and future conditions indicate that there will be upward shifting to higher elevation area as the temperature gradually warming. This indication is aligned with certain studies that predicted a shift of forest ecosystems to a higher altitude under projected future climate conditions (e.g., Walther et al. 2003; Bertrand et al. 2011). Even though the shifting figures are relatively small, the finding still illustrates the changes in the suitability level of certain areas/regions affected by climate changes. The increase in temperature and possible occurrence of severe drought, as indicated by precipitation variability in those areas, would increase the level of stress the plants received from its surrounding (Kelly and Goulden 2008). Therefore, it is expected to reduce the species' capability to survive in the drier-warmer lower parts of its altitude range (Allen and Breshears 1998; Lenoir et al. 2008) and increase its competitive ability and tolerance in the wetter and cooler upper parts of its altitude range (Parmesan 2006).

Alongside the climatic factors, the ability of $S$. zollingeriana to disperse outside of its current geographical range is also likely to be governed by ecological determinants that affect propagule (in case of Selaginella species, is its spore) departure, transport, and arrival, respectively. Several factors potentially will be affected by climate conditions in the process of species' dispersal, i.e., plant fecundity, dispersal pathways, spore delivery sites, and biotic interactions at the new geographical sites (Hampe 2011). Clark et al. (2001) demonstrated on theoretical grounds that variation in fecundity (net productive rate) can exert strong effects on expansion rates. The authors highlight the finding that climate-driven changes in population fecundity could play a key role in future range expansions, even though the authors emphasized regarding fecundity consideration as a variable parameter considerably reduces model-based estimates of past expansion rates. Moreover, numerous experimental studies have shown that elevated $\mathrm{CO} 2$ level can significantly increase the pollen, spores, flower, and seed output of individual plants (LaDeau and Clark 2001, 2006a; Jablonski et al. 2002; Stiling et al. 2004; Way et al. 2010), although this increase may be accompanied by decreasing quality of the seeds (most notably is in terms of nitrogen content) (Jablonski et al. 2002; Stiling et al. 2004; Way et al. 2010). In addition, a number of field studies have successfully monitored multi-year patterns of plants fecundity in populations near the (climate-governed) leading edge of species ranges (i.e., Pigott and Huntley 1981; Hofgaard 1993; Holm 1994; Despland and Houle 1997; Meunier et al. 2007). Unsurprisingly, propagules productions are typically linked with favorable climatic conditions. Consequently, future warming may be expected to result in higher long-term average fecundity; however, it may be accompanied by irregular propagule production and decreased propagule quality. Nevertheless, further investigation is needed to understand more about projected future climate conditions with plants fecundity (e.g., genetic-evolutionary component, Allee effects, etc.).

The trajectories of migrating $S$. zollingeriana's propagules are expected to largely be determined by the landscape context of the Indonesian archipelago. It is well known from phylogeographical studies that major geographic barriers have influenced past population and range dynamics (Hewitt 2010). The strong contextdependence of long-distance dispersal and colonization resulting events is possibly the main reason for the exceptionally peculiar nature of past range expansions $(\mathrm{Hu}$ et al. 2009; Jackson et al. 2009). Therefore, a better understanding of how the biotic and abiotic environment provokes expansion routes and dispersal pathways is critical for improving predictions of future range shifts. Investigation of future climate changes that might affect dispersal pathways is surprisingly limited. Recently, Trenberth et al. (2007), Kuparin et al. (2009), and Nathan et al. (2011) found that the combination of increasing air temperature and increasing frequency of winds and storms can indeed favor the frequency of long-distance winddispersal of propagule, although the effect seems rather small. The impact of future climate change on the behavior of biotic dispersal agents is even more difficult to predict. The only well-known prediction of the effect of climate change on biotic dispersal is that climate-driven changes of bird migration routes and wintering grounds could result in 
substantial changes in the abundance of avian seed dispersers (Berthold et al. 1992; Rivalan et al. 2007; Carlo and Morales 2008). Since there is limited information on how $S$. zollingeriana is dispersed in Java, it is difficult on which aspect of propagule dispersal of the species will be significantly affected by future climate changes.

From a landscape perspective, climate changes can result in loosening or constricting climate constraints on plants in the growing area available for colonization as well as increasing connectivity for patches (Hampe 2011). When climate constraints loosening, the propagule pressure required for establishing self-sustaining populations would rapidly decrease since both seed sources and suitable establishment sites become more abundant. Otherwise, constricted climate constraints will increase pressure for propagule to establish self-sustaining populations (Simberloff 2009). Furthermore, climate change is not only influencing the movement and establishment of recruiting colonizer but also imply indirect effects through its mediation of biotic interactions that intervene at different stages of the recruitment process. The fundamental complexity and context-dependence of such biotic interactions burden predictions with a great uncertainty upon future changes in biotic interactions and their consequences on the survival of expanding species (Mitchell et al. 2006; Parmesan 2006). Therefore, further investigations on the true climate constraints of $S$. zollingeriana and its biotic interactions in its native region are pivotal to predict the survival of species' colonization in the new regions.

The major limitations for modeling plant expansion range are the assumption that species are at the equilibrium with their environment and the assumption of niche conservatism, wherein climate niches of the species from the native area can be projected onto new geographical spaces (Gallien et al. 2012; Barbet-Massin 2018). Although S. zollingeriana has a sufficiently long history in Java and has been used for traditional uses by the communities to have sampled most of the environmental conditions, its distribution may not yet at equilibrium. Moreover, recent model accuracy techniques (such as TSS) might not be appropriate for range expansion modeling. The not-so-high TSS value of the model (0.789) could also mean either that the variables used in this study do not genuinely capture the enviro-climatic determinants of the species' niche distribution, or that the variables are correct and the species has a huge potential for spreading wider into the new range of suitable niche.

There are three presumptive factors that are likely to affect the accuracy of the model. Firstly, MaxEnt assumes the current distribution data of the species provides a good indication of their true potential range. Whereby this is not entirely correct, the potential range will be under- or overestimated. The potential range could be overestimated for species occurring in few scattered locations throughout the entire area of study, whereas it could be underestimated for species that currently exist in a small, clumped range. Secondly, despite the bias corrections conducted, unrepresentative data from field studies and databases may have led to an underestimation of the current and potential distribution of less conspicuous species. Lastly, the process of averaging the climatic suitability values per $1 \mathrm{~km}^{2}$ cell assumes that the mean values represent the location where the species occurs. The likelihood of a significant error in this assumption depends on the variability of the climatic factors in the cells in the study area. At the broad scale at which this study is intended to collect information regarding the possibility of suitable niche in the other islands of Indonesia, these factors may not have a substantial effect on the overall accuracy or usefulness of the results. Further detailed assessments, however, will be necessary for further utilization of this study (e.g., to inform management and planning, conservation efforts, etc.). Despite the limitations mentioned above, it is reasonable to presume the robustness of the predicted trends of suitable niche distribution at the level of acceptable for a primary study. The construction of a more ideal model requires the availability of multiple compounding factors which are expected to have a direct or indirect effect on the target species and its associated biota. Potential human-induced land use/land cover changes in the potential new region of occupation, biotic interactions between species in the new regional ecosystems, more detailed enviro-climatic data, and better representation of variability of species' niche are several examples of variables that are expected to be pivotal in constructing a more ideal model. Nevertheless, with the currently available data, we could make inferences that if the propagules of $S$. zollingeriana could be dispersed across the country, the availability of potentially suitable habitat could be disturbed by the recent and future changes in climate conditions. Therefore, the successfulness of $S$. zollingeria's expansion could severely be hindered by future climate changes.

\section{REFERENCES}

Ackerly DD, CA Knight, SB Weiss, K Barton, KP Starmer 2002 Leaf size, specific leaf area and microhabitat distribution of woody plants in a California chaparral: contrasting patterns in species level and community level analyses. Oecologia 130:449-457. DOI: 10.1007/s004420100805.

Aguirre-Gutiérrez J, Carvalheiro LG, Polce C, van Loon EE, Raes N, Reemer M, et al. 2013. Fit-for-purpose: species distribution model performance depends on evaluation criteria - dutch hoverflies as a $\begin{array}{lllll}\text { case study. PLoS ONE } 8 \text { (5): e63708. DOI: } & \end{array}$ 10.1371/journal.pone.0063708.

Allen CD, Breshears DD. 1998. Drought-induced shift of a forestwoodland ecotone: Rapid landscape response to climate variation. Proc Natl Acad Sci USA 95: 14839-14842.

Allouche O, Tsoa A, Kadmon R. 2006. Assessing the accuracy of species distribution models: Prevalence, kappa and the true skill statistic (TSS). J Appl Ecol 43(1): 1223-1232. DOI: 10.1111/j.13652664.2006.01214.x.

Alston AHG. 1934. The genus Selaginella in the Malay Peninsula. Gard Bull Strait Settl 8: 41-62.

Alston AHG. 1935a. The Selaginella of the Malay Islands: I. Java and the Lesser Sunda Islands. Bull Jard Bot Buitenzorg 3(13): 432-442.

Alston AHG. 1935b. The Philippines species of Selaginella. Philippines J Sci 58: 359-383.

Alston AHG. 1937. The Selaginella of the Malay Islands: II. Sumatra. Bull Jard Bot Buitenzorg 3(14): 175-186.

Alston AHG. 1940. The Selaginella of the Malay Islands: III. Celebes and the Moluccas. Bull Jard Bot Buitenzorg 3 (16): 343-350. 
Araujo M, Peterson AT. 2012. Uses and misuses of bioclimatic envelope modeling. Ecology 93(7): 1527-1539. DOI: 10.1890/11-1930.1.

Araújo MB, Guisan A. 2006. Five (or so) challenges for species distribution modelling. $\mathrm{J}$ Biogeogr 33: 1677-1688. DOI 10.1111/j.1365-2699.2006.01584.x.

Austin MP. 2002. Spatial prediction of species distribution: an interface between ecological theory and statistical modeling. Ecol Modell 157 (1): 101-118. DOI: 10.1016/S0304-3800(02)00205-3.

Bahn V, McGill BJ. 2007. Can niche-based distribution models outperform spatial interpolation? Global Ecol Biogeogr 16: 733-742. DOI: $10.1111 / \mathrm{j} .1466-8238.2007 .00331 . x$.

Bale JS, Masters GJ, Hodkinson ID, Awmack C, Bezemer TM, Brown VK, Butterøield J, Buse A, Coulson JC, Farrar J, Good JEG, Harrington R, Hartley S, Jones TH, Lindroth RL, Press MC, Symrnioudis I, Watt AD, Whittaker JB. 2002. Herbivory in global climate change research: direct effects of rising temperature on insect herbivores. Glob Chan Biol 8: 1-16. DOI: 10.1046/j.13652486.2002.00451.x.

Barbet-Massin M, Rome Q, Villemant C, Courchamp F. 2018. Can species distribution models really predict the expansion of invasive species?. PLoS ONE 13(3): 1-14. DOI: 10.1371/journal.pone.0193085.

Bedia, Joaqu'in, Herrera, Sixto, Guti'errez, Jose Manuel. 2013. Dangers of using global bioclimatic datasets for ecological niche modeling. Limitations for future climate projections. Glob Planet Change 107: 1-12. DOI: 10.1016/j.gloplacha.2013.04.005.

Berthold P, Helbig AJ, Mohr G, Querner U. 1992. Rapid microevolution of migratory behaviour in a wild bird species. Nature 360: 668-670. DOI: $10.1038 / 360668 \mathrm{a} 0$

Bertrand R, Lenoir J, Piedallu C, Riofrío-Dillon G, de Ruffray P, Vidal C et al. 2011. Changes in plant community composition lag behind climate warming in lowland forests. Nature 479(7374): 517-520. DOI: $10.1038 /$ nature10548.

Bonan GB. 2008. Forests and climate change: forcings, feedbacks, and the climate benefits of forests. Science 320 (5882): 1444-1449. DOI 10.1126/science.1155121.

Boria RA, Olson LE, Goodman SM, Anderson RP. 2014. Spatial filtering to reduce sampling bias can improve the performance of ecological niche models. Ecol Modell 275: 73-77. DOI: 10.1016/j.ecolmodel.2013.12.012.

Bradley BA, Wilcove DS, Oppenheimer M. 2010. Climate change increases risk of plant invasion in the Eastern United States. Biol Invasions 12: 1855-1872. DOI: 10.1007/s10530-009-9597-y.

Brown JL. 2014. SDMtoolbox: A python-based GIS toolkit for landscape genetic, biogeographic, and species distribution model analyses. Meth Ecol Evol 5(7): 694-700. DOI: 10.1111/2041-210X.12200.

Byrt T, Bishop J, Carlin JB. 1993. Bias, prevalence and kappa. J Clin Epidemiol 46 (5): 423-429. DOI: 10.1016/0895-4356(93)90018-v.

Carlo TA, Morales JM. 2008. Inequalities in fruit-removal and seed dispersal: consequences of bird behaviour, neighbourhood density and landscape aggregation. J Ecol 96: 609-618. DOI: 10.1111/j.13652745.2008.01379.x.

Chang HM, Chiou WL, Wang JC. 2012. Flora of Taiwan, Selaginellaceae. Endemic Species Research Institute, Nantou, Taiwan.

Clark JS, Lewis M, Horvath L. 2001. Invasion by extremes: Population spread with variation in dispersal and reproduction. Am Nat 157 (5): 537-554. DOI: $10.1086 / 319934$.

Clark JS, Lewis M, MacLachlan JS, HilleRisLambers J. 2003. Estimating population spread: What can we forecast and how well?. Ecology 84 1979-1988. DOI: 10.1890/01-0618.

Clarke L, Edmonds J, Jacoby H, Pitcher H, Reilly J, Richels R. 2007. Scenarios of Greenhouse Gas Emissions and Atmospheric Concentrations. Sub-report 2.1A of Synthesis and Assessment Product 2.1 by the U.S. Climate Change Science Program and the Subcommittee on Global Change Research. Department of Energy, Office of Biological \& Environmental Research, Washington DC

Collins WJ, Bellouin N, Doutriaux-Boucher M, Gedney N, Halloran P et al. 2011. Development and evaluation of an Earth-System modelHadGEM2. Geosci Model Dev Discuss 4: 997-1062. DOI: 10.5194/gmdd-4-997-2011

Deeba F, Pandey V, Pathre U, Kanojiya U. 2009. Proteome analysis of detached fronds from a resurrection plant Selaginella bryopterisresponse to dehydration and rehydration. J Proteomics Bioinform Volume 2 (2): 108-116. DOI: 10.4172/jpb.1000067.

Dudík, M., Schapire RE, Steven J Phillips SJ. 2005. Correcting sample selection bias in maximum entropy density estimation. NIPS'05:
Proceedings of the 18th International Conference on Neural Information Processing Systems, December 2005. The MIT Press, Boston.

Early R, Sax DF. 2014. Climatic niche shifts between species' native and naturalized ranges raise concern for ecological forecasts during invasions and climate change. Glob Ecol Biogeogr 23: 1356-1365. DOI: $10.1111 / \mathrm{geb} .12208$.

Ebihara A, Fraser-Jenkins CR, Parris BS, et al. 2012. Rare and threatened pteridophytes of Asia 1. An enumeration of narrowly distributed taxa. Bull Natl Mus Nat Sci Ser B 38(3): 93-119.

Eickmeier WG. 1986. The correlation between high-temperature and desiccation tolerances in a poikilohydric desert plant. Can J Bot 64(1): 611-617. DOI: 10.1139/b86-078.

Elith J, Graham CH, Anderson P, Dudik M, Ferrier S, et al. 2006. Novel methods improve prediction of species distributions from occurrence data. Ecograph 29: 129-136. DOI: 10.1111/j.2006.09067590.04596.x.

Elith J, Phillips SJ, Hastie T, Dudik M, Chee YE, Yates CJ. 2011. A statistical explanation of Maxent for ecologists. Divers Distrib 17: 43 57. DOI: $10.1111 / \mathrm{j} .1472-4642.2010 .00725 . x$.

ESRI 2011. ArcGIS Desktop: Release 10. Redlands, CA: Environmental Systems Research Institute.

Excoffier L, Foll M, Petit RJ. 2009, Genetic consequences of range expansions, Ann Rev Ecol Evol Syst 40: 481-501. DOI: 10.1146/annurev.ecolsys.39.110707.173414.

Feinstein AR, Cicchetti DV. 1990. High agreement but low kappa: I. The problems of two paradoxes. J Clin Epidemiol 43: 543-549. DOI: 10.1016/0895-4356(90)90158-L.

Fourcade Y, Engler JO, Rodder D, Secondi J. 2014. Mapping species distributions with MAXENT using a geographically biased sample of presence data: A performance assessment of methods for correcting sampling bias. PLoS ONE 9 (5): 678-692. DOI: 10.1371/journal.pone.0097122.

Gallien L, Douzet R, Pratte S, Zimmermann NE, Thuiller W. 2012. Invasive species distribution model show violating the equilibrium assumption can create new insights. Glob Ecol Biogeogr 21: 11261136. DOI: $10.1111 / \mathrm{j} .1466-8238.2012 .00768 . x$.

GBIF. 2016. GBIF Occurrence Download. DOI: 10.15468/dl.ywhpmz [29th February 2016]

Giljohann KM, Hauser CE, Williams NSG, Moore JL. 2011. Optimizing invasive species control across space: Willow invasion management in the Australian Alps. J Appl Ecol 48: 1286-1294. DOI: 10.1111/j.1365-2664.2011.02016.x.

Gilman SE, Urban MC, Tewksbury J, Gilchrist GW, Holt RD. 2010. A framework for community interactions under climate change. Trend Ecol Evol 25(6): 325-331. DOI: 10.1016/j.tree.2010.03.002.

Google Earth Pro. 2017. Download Google Earth Pro for PC, Mac, or Linux. www.google.com/earth/download/gep/agree.html

Google Maps. 2014. Royal Roads University. Retrieved from https: $/ / \mathrm{www}$.google.com/maps/d/viewer?mid=ziZA4YH0pTUs.ktJc02G0F O4\&ie $=$ UTF8\&oe $=U T F 8 \& \mathrm{msa}=0$

Gu WD, Swihart RK. 2004. Absent or undetected? Effects of nondetection of species occurrence on wildlife habitat models. Biol Conser 116: 195-203. DOI: 10.1016/S0006-3207(03)00190-3.

Guralnick RP, Wieczorek J, Beaman R, Hijmans RJ. 2006. BioGeomancer: Automated georeferencing to map the world's biodiversity data. PLoS Biol 4 (11): e381. DOI: 10.1371/journal.pbio.0040381.

Halvorsen R, Mazzoni S, Bryn A, Bakkestuen V. 2015. Opportunities for improved distribution modelling practice via a strict maximum likelihood interpretation of MaxEnt. Ecography 38:172-183. DOI: 10.1111/ecog.00565.

Hampe A. 2011. Plants on the move: The role of seed dispersal and initial population establishment for climate-driven range expansions. Acta Oecologica 37: 1-26. DOI: 10.1016/j.actao.2011.05.001.

Harvell CD, Mitchell CE, Ward JR, Altizer S, Dobson AP, Ostfeld RS, Samuel MD. 2002. Climate warming and disease risks for terrestrial and marine biota. Science 296 (5576): 2158-2162. DOI: 10.1126/science. 1063699 .

Hastings A, Cuddington K, Davies KF, Dugaw CJ, Elmendorf S, Freestone A, Harrison S, Holland M, Lambrinos J, Malvadkar U, Melbourne BA, Moore K, Taylor C, Thomson D. 2005. The spatial spread of invasions: new developments in theory and evidence. Ecol Lett 8: 91-101. DOI: 10.1111/j.1461-0248.2004.00687.x.

Hawkins ED, Osborne TM, Ho CK, Challinor AJ. 2013. Calibration and bias correction of climate projections for crop modeling: An idealised 
case study over Europe. Agric For Meteorol 170: 19-31. DOI: 10.1016/j.agrformet.2012.04.007.

Hewitt GM. 2000. The genetic legacy of the Quaternary ice ages. Nature 405: 907-913. DOI: $10.1038 / 35016000$.

Hijmans RJ. 2012. Cross-validation of species distribution models: Removing spatial sorting bias and calibration with a null model. Ecology 93: 679-688. DOI: 10.1890/11-0826.1.

Hofgaard A. 1993. Seed rain quantity and quality, 1984-1992, in a high altitude old-growth spruce forest, northern Sweden. New Phytol 125: 635-640. DOI:10.1111/J.1469-8137.1993.TB03913.X.

Holm SO. 1994. Reproductive patterns of Betula pendula and $B$. pubescens Coll. along a regional altitudinal gradient in Northern Sweden. Ecography 17: 60-72. DOI: 10.1111/j.16000587.1994.tb00077.x.

Hu FS, Hampe A, Petit RJ. 2009. Paleoecology meets genetics: Deciphering past vegetational dynamics. Front Ecol Environ 7: 371 379. DOI: $10.1890 / 070160$.

Hu XG, Jin Y, Wang XR, Mao JF, Li Y. 2015. Predicting impacts of future climate change on the distribution of the widespread conifer Platycladus orientalis. PLoS ONE 10(7): e0132326. DOI 10.1371/journal.pone.0132326

IPCC. 2014. In: Solomon S, Qin D, Manning M, Chen Z, Marquis M, Averyt KB, Tignor M, Miller HL (eds). Climate change 2014: The physical science basis. Contribution of Working Group I to the Fifth Assessment Report of the Intergovernmental Panel on Climate Change. Cambridge University Press, Cambridge, UK.

Jablonski LM, Wang XZ, Curtis PS. 2002. Plant reproduction under elevated CO2 conditions: A meta-analysis of reports on 79 crop and wild species. New Phytol 156: 9-26. DOI: 10.1046/j.14698137.2002.00494.x.

Jackson ST, Betancourt JL, Booth RK, Gray ST. 2009. Ecology and the ratchet of events: Climate variability, niche dimensions, and species distribution. Proc Natl Acad Sci USA 106:19685-19692. DOI: 10.1073/pnas.0901644106.

Jagels R. 1970. Photosynthetic apparatus in Selaginella. I. Morphology and photosynthesis under different light and temperature regimes. Can J Bot 48(1): 1843-1852. DOI: 10.1139/b70-270.

Jimenez-Valverde A, Peterson AT, Soberô̂n J, Overton JM, Aragô̂n P, Lobo JM. 2011. Use of niche models in invasive species risk assessments. Biol Invasions 13: 2785-2797. DOI: 10.1007/s10530011-9963-4.

Jimenez-Valverde A. 2012. Insights into the area under the receiver operating characteristic curve (AUC) as a discrimination measure in species distribution modeling. Glob Ecol Biogeogr 21: 498-507. DOI: 10.1111/j.1466-8238.2011.00683.x

Jimenez-Valverde A. 2014. Threshold-dependence as a desirable attribute for discrimination assessment: Implications for the evaluation of species distribution models. Biodiv Conserv 23 (1): 369-385. DOI: 10.1007/s10531-013-0606-1.

Kelly AE, Goulden ML. 2008. Rapid shifts in plant distribution with recent climate change. Proc Natl Acad Sci USA 105 (33): 11823 11826; DOI: 10.1073/pnas.0802891105.

Kolbe JJ, Glor RE, Schettino LR, Lara AC, Larson A, Losos JB. 2004 Genetic variation increases during biological invasion by a Cuban lizard. Nature 431: 177-181. DOI: 10.1038/nature02807.

Körner C. 2007. The use of altitude in ecological research. Trends Ecol Evol 22: 569-574. DOI: 10.1016/j.tree.2007.09.006.

Kramer AM, Annis G, Wittmann ME, Chadderton WL, Rutherford ES Lodge DM et al. 2017. Suitability of Laurentian Great Lakes for invasive species based on global species distribution models and local habitat. Ecosphere 8: 1-17. DOI: 10.1002/ecs2.1883.

Kramer-Schadt S, Niedballa J, Pilgrim JD, Schroder B, Lindenborn J, et al. 2013. The importance of correcting for sampling bias in Maxent species distribution models. Divers Distrib 19: 1366-1379. DOI: 10.1111/ddi.12096

La Morgia V, Malenotti E, Badino G, Bona F. 2011. Where do we go from here? Dispersal simulations shed light on the role of landscape structure in determining animal redistribution after reintroduction. Landscape Ecol DOI: 10.1007/s10980-011-9621-3.

LaDeau SL, Clark JS. 2001. Rising CO2 levels and the fecundity of forest trees. Science 292: 95-98. DOI: 10.1126/science.1057547. DOI: 10.1111/j.1354-1013.2006.01137.x

LaDeau SL, Clark JS. 2006a. Elevated CO2 and tree fecundity: The role of tree size, inter-annual variability and population heterogeneity. Glob Change Biol 12(5):822-833. DOI: $10.1111 / \mathrm{j} .1365-$ 2486.2006.01137.x.
Lantz CA, Nebenzah E. 1996. Behavior and interpretation of the kappa statistic: resolution of the two paradoxes. J Clin Epidemiol 49 (4): 431-434. DOI: 10.1016/0895-4356(95)00571-4.

Lecocq T, Rasmont P, Harpke A, Schweiger O. 2016. Improving international trade regulation by considering intraspecific variation for invasion risk assessment of commercially traded species: The Bombus terrestris case. Conserv Lett 9: 281-289. DOI: 10.1111/conl.12215.

Lenoir J, Gégout J, Marquet P, De Ruffray P, Brisse H. 2008. A significant upward shift in plant species optimum elevation during the $20^{\text {th }}$ century. Science 320 (5884): 1768-1771. DOI: 10.1126/science.1156831.

Li W, Guo Q. 2013. How to assess the prediction accuracy of species presence-absence models without absence data?. Ecograph 36(7): 788-799. DOI: 10.1111/j.1600-0587.2013.07585.x

Li ZJ, Tan BC. 2005. A review of the species diversity of Selaginella in Fujian Province of China. Acta Phytotax Sin 43(1): 50-59. DOI: 10.1360/aps040081.

Liu C, Newell G, White M. 2016. On the selection of thresholds for predicting species occurrence with presence-only data. Ecol Evol 6(1): 337-348. DOI: 10.1002/ece3.1878.

Lobo JM, Jiménez-Valverde A, Real R. 2008. AUC: A misleading measure of the performance of predictive distribution models. Glob Ecol Biogeogr 17(2): 145-151. DOI: 10.1111/j.14668238.2007.00358.x.

Manel S, Williams HC, Ormerod SJ. 2002. Evaluating presence-absence models in ecology: The need to account for prevalence. J Appl Ecol 38 (5): 921-931. DOI: 10.1046/j.1365-2664.2001.00647.x

Medley KA. 2010. Niche shifts during the global invasion of the Asian tiger mosquito, Aedes albopictus Skuse (Culicidae), revealed by reciprocal distribution models. Glob Ecol Biogeogr 19: 122-133. DOI: $10.1111 /$ j.1466-8238.2009.00497.x.

Merow C, Smith MJ, Silander JA. 2013. A practical guide to MaxEnt for modeling species' distributions: What it does, and why inputs and settings matter. Ecography 36(10):1058-1069. DOI: 10.1111/j.16000587.2013.07872.x

Meunier C, Sirois L, Bégin Y. 2007. Climate and Picea mariana seed maturation relationships: A multi-scale perspective. Ecol Monogr 77: 361-376. DOI: 10.1890/06-1543.1.

Miller N, Estoup A, Toepfer S, Bourguet D, Lapchin L, Derridj S, Kim KS, Reynaud P, Furlan L, Guillemaud T. 2005. Multiple transatlantic introductions of the western corn rootworm. Science 310: 992. DOI: DOI: $10.1126 /$ science. 1115871 .

Mitchell CE, Agrawal AA, Bever JD, Gilbert GS, Hufbauer RA, Klironomos JN, Maron JL, Morris WF, Parker IM, Power AG, Seabloom EW, Torchin ME, Vázquez DP. 2006. Biotic interactions and plant invasions. Ecol Lett 9: 726-740. DOI: 10.1111/j.14610248.2006.00908.x.

Mod HK, Scherrer D, Luoto M, Guisan A. 2016. What we use is not what we know: environmental predictors in plant distribution models. J Veg Sci 27(6): 1308-1322. DOI: 10.1111/jvs.12444.

Montgomery R, Roloff GJ, Hoef M. 2011. Implications of ignoring telemetry error on inference in wildlife resource use models. J Wildl Manag 75: 702-708. DOI: 10.1002/jwmg.96.

Morales NS, Fernández IC, Baca-González V. 2017. MaxEnt's parameter configuration and small samples: Are we paying attention to recommendations? A systematic review. Peer J 5:e3093. DOI $10.7717 /$ peerj.3093

Moss RH, Edmonds JA, Hibbard KA, Manning MR, Rose SK, et al. 2010. The next generation of scenarios for climate change research and assessment. Nature 463: 747-756. DOI: 10.1038/nature08823.

Nathan R, Horvitz N, He Y, Kuparinen A, Schurr FM, Katul GG. 2011. Spread of North American wind-dispersed trees in future environments. Ecol Lett 14: 211-219. DOI: 10.1111/j.14610248.2010.01573.x.

Nathan R, Perry G, Cronin JT, Strand AE, Cain ML. 2003. Methods for estimating long-distance dispersal. Oikos 103: 261-273. DOI: 10.1034/j.1600-0706.2003.12146.x

Nathan R. 2006. Long-distance dispersal of plants. Science 313: 786-788. DOI: $10.1126 /$ science. 1124975

Norris D. 2014. Model thresholds are more important than presence location type: Understanding the distribution of lowland tapir (Tapirus terrestris) in a continuous Atlantic forest of Southeast Brazil. Trop Conserv Sci 7 (3): 529-547. DOI: 10.1177/194008291400700311. 
O’Donnell MS, Ignizio DA. 2012. Bioclimatic predictors for supporting ecological applications in the conterminous United States: U.S. Geological Survey Data Series 691. U.S. Geological Survey, Reston, Virginia. DOI: 10.3133/ds691.

Pandey V, Sanjay R, Farah D, et al. 2010. Desiccation-induced physiological and biochemical changes in resurrection plant, Selaginella bryopteris. J Plant Physio 167: 1351-1359. DOI: 10.1016/j.jplph.2010.05.001.

Parmesan C, Gaines S, Gonzalez L, Kaufman DM, Kingsolver J, Peterson AT, Sagarin R, 2005. Empirical perspectives on species borders: From traditional biogeography to global change. Oikos 108 (1): 5875. DOI: $10.1111 /$ j.0030-1299.2005.13150.x

Parmesan C. 2006. Ecological and evolutionary responses to recent climate change. Annu Rev Ecol Evol Syst 37:637-669. DOI 10.1146/annurev.ecolsys.37.091305.110100.

Parravicini V, Azzurro E, Kulbicki M, Belmaker J. 2015. Niche shift can impair the ability to predict invasion risk in the marine realm: An illustration using Mediterranean fish invaders. Ecol Lett 18: 246-253. DOI: $10.1111 /$ ele.12401.

Pearson RG, Christopher J. Raxworthy, Nakamura M. 2007. Predicting species distributions from small numbers of occurrence records: A test case using cryptic geckos in Madagascar. J Biogeogr 34: 102-117. DOI: $10.1111 / \mathrm{j} .1365-2699.2006 .01594 . x$

Peterson AT, Papes M, Soberon J. 2008. Rethinking receiver operating characteristic analysis applications in ecological niche modeling. Ecol Modell 213: 63-72. DOI: 10.1016/j.ecolmodel.2007.11.008.

Peterson AT, Soberon J, Pearson RG et al. 2011. Ecological niches and geographic distributions. Princeton Univ Press, New Jersey. DOI: 10.23943/princeton/9780691136868.003.0009.

Peterson AT, Soberon J. 2012. Species distribution modeling and ecological niche modeling: getting the concepts right. Nat Conserv 10(2): 102-107. DOI: 10.4322/natcon.2012.019.

Phillips SJ, Anderson RP, Dudík M, Schapire RE, Blair ME. 2017 Opening the black box: an open-source release of Maxent. Ecography 40: 887-893. DOI: 10.1111/ecog.03049.

Phillips SJ, Dudik M. 2008. Modeling of species distributions with Maxent: New extensions and a comprehensive evaluation. Ecography 31: 161-175. DOI: 10.1111/j.0906-7590.2008.5203.x.

Phillips SJ, Elith J. 2010. POC plots: Calibrating species distribution models with presence-only data. Ecology 91(1): 2476-2484. DOI: 10.1890/09-0760.1.

Pigott CD, Huntley JP. 1981. Factors controlling the distribution of Tilia cordata at the northern limits of its geographical range. III. Nature and cause of seed sterility. New Phytol 87: 817-839. DOI: 10.1111/j.1469-8137.1981.tb01716.x.

QGIS Development Team. 2017. QGIS Geographic Information System. Open Source Geospatial Foundation. http://qgis.osgeo.org.

Radosavljevic A, Anderson RP. 2013. Making better Maxent models of species distributions: complexity, overfitting and evaluation. J Biogeogr 41: 629-643. DOI: 10.1111/jbi.12227.

Ramirez-Villegas J, Challinor AJ, Thornton PK, Jarvis A. 2013 Implications of regional improvement in global climate models for agricultural impact research. Environ Res Lett 8: 1-12. DOI 10.1088/1748-9326/8/2/024018.

Riahi K, Rao S, Krey V et al. 2011. RCP 8.5-A scenario of comparatively high greenhouse gas emissions. Clim Chang 109(33): 364-379. DOI: 10.1007/s10584-011-0149-y.

Rivalan P, Frederiksen M, Loïs G, Julliard R, 2007. Contrasting responses of migration strategies in two European thrushes to climate change. Glob Chang Biol 13: 275-287. DOI: 10.1111/j.13652486.2006.01290.x.

Sakai AK, Allendorf FW, Holt JS, Lodge DM, Molofsky J, With KA, Baughman S, Cabin RJ, Cohen JE, Ellstrand NC, McCauley DE, O'Neil P, Parker MI, Thompson JN, Weller SG (2001) The population biology of invasive species. Ann Rev Ecol Syst 32:305332. DOI: 10.1146/annurev.ecolsys.32.081501.114037.

Saxe H, Cannell MGR, Johnsen B, Ryan MG, Vourlitis G. 2001. Tree and forest functioning in response to global warming. New Phytol 149: 369-399. DOI: 10.1046/j.1469-8137.2001.00057.x.

Setyawan AD, Supriatna J, Darnaedi D, Rokhmatuloh, Sutarno, Sugiyarto, Nursamsi I, Komala WR, Pradan P. 2017. Impact of climate change on potential distribution of xero-epiphytic Selaginellas (Selaginella involvens and S. repanda) in Southeast Asia. Biodiversitas 18(4): 1680-1695. DOI: 10.13057/biodiv/d180448.

Setyawan AD, Supriatna J, Nisyawati, Nursamsi I, Sutarno, Sugiyarto, Sunarto, Pradan P, Budiharta S, Pitoyo A, Suhardono S, Setyono P,
Indrawan M. 2020a. Anticipated climate changes reveal shifting in habitat suitability of high-altitude selaginellas in Java, Indonesia. Biodiversitas 21: 5482-5497. DOI: 10.13057/biodiv/d211157.

Setyawan AD, Supriatna J, Nisyawati, Nursamsi I, Sutarno, Sugiyarto, Sunarto, Pradan P, Budiharta S, Pitoyo A, Suhardono S, Setyono P, Indrawan M. 2020b. Predicting potential impacts of climate change on the geographical distribution of mountainous selaginellas in Java, $\begin{array}{llll}\text { Indonesia. Biodiversitas 21: 4866-4877. DOI: } & \end{array}$ 10.13057/biodiv/d211053.

Setyawan AD, Sutarno, Sugiyarto. 2013. Species diversity of Selaginella in Mount Lawu, Java, Indonesia. Biodiversitas 14: 1-9. DOI: 10.13057/biodiv/d140101

Shigesada N, Kawasaki K, Takeda Y. 1995. Modeling stratified diffusion in biological invasions. Am Natur 146 (2\}: 229-251. DOI: $10.1086 / 285796$.

Simberloff D. 2009. The role of propagule pressure in biological invasions. Annu Rev Ecol Evol Syst 40:81-102. DOI: 10.1146/annurev.ecolsys.110308.120304.

Skellam JG. 1951. Random dispersal in theoretical populations. Biometrika 38: 196-218.

Skov F, Svenning JC. 2004. Potential impact of climatic change on the distribution of forest herbs in Europe. Ecography 27: 366-380, 2004 DOI: 10.1111/j.0906-7590.2004.03823.x.

Solomon S, Qin D, Manning M, Chen Z, Marquis M, Averyt KB, Tignor M, Miller HL (eds.). 2007. Contribution of Working Group I to the Fourth Assessment Report of the Intergovernmental Panel on Climate Change. Cambridge University Press, Cambridge, UK.

Soni DK, Ranjan S, Singh R, et al. 2012. Photosynthetic characteristics and the response of stomata to environmental determinants and ABA in Selaginella bryopteris, a resurrection spike moss species. Plant Sci 191 (1): 43-52. DOI: 10.1016/j.plantsci.2012.04.011.

Soria-auza RW. 2009. Diversity and Biogeography of Ferns and Birds in Bolivia: Applications of GIS-Based modeling approaches. [Dissertation]. Universität Göttingen, Göttingen.

Stiling P, Moon D, Hymus G, Drake B. 2004. Differential effects of elevated $\mathrm{CO} 2$ on acorn density, weight, germination, and predation among three oak species in a scrub-oak forest. Glob Chang Biol 10: 228-232. DOI: 10.1111/j.1365-2486.2004.00728.x.

Stolar J, Nielsen S. 2015. Accounting for spatially biased sampling effort in presence-only species distribution modelling. Divers Distrib 21: 595-608. DOI: $10.1111 /$ ddi.12279.

Struebig MJ, Wilting A, Gaveau DLA, Meijaard E, Smith RJ.2015. Targeted Conservation to Safeguard a Biodiversity Hotspot from Climate and Land-Cover Change. Curr Biol 25: 372-378. DOI: 10.1016/j.cub.2014.11.067.

Tabor K, Williams JW. 2010. Globally downscaled climate projections for assessing the conservation impacts of climate change. Ecol Appl 20(2): 554-565. DOI: 10.1890/09-0173.1.

Thrasher B, Maurer EP, McKellar C, Duffy PB. 2012.Technical Note: Bias correcting climate model simulated daily temperature extremes with quantile mapping. Hydrol Earth Syst Sci 16: 3309-3314. DOI: 10.5194/hess-16-3309-2012.

Trenberth KE, Jones PD, Ambenje P, Bojariu R, Easterling D, Klein-Tank A, Parker D, Rahimzadeh F, Renwick JA, Rusticucci M, Soden B, Zhai B. 2007. Observations: Surface and Atmospheric Climate Change. Climate Change 2007: The Physical Science Basis. Cambridge University Press, Cambridge, UK.

Tsai JL, Shieh WC. 1994. Selaginellaceae. In: Huang TC (eds). Flora of Taiwan. Vol. 1. 2nd ed. Department of Botany, National Taiwan University, Taipei.

Tulloch AIT, Tulloch VJD, Evans MC, Mills M. 2014. The value of using feasibility models in systematic conservation planning to predict landholder management uptake. Conserv Biol 28: 1462-1473. DOI: 10.1111/cobi.12403.

Urban MC, Phillips BL, Skelly DK, Shine R. 2008. A toad more traveled: the heterogeneous invasion dynamics of cane toads in Australia. Amer Natur 171: E134 -E148. DOI: 10.1086/527494.

Van Der WJ, Shoo LP, Graham C, Williams SE. 2009. Selecting pseudoabsence data for presence-only distribution modeling: How far should you stray from what you know?. Ecol Model 220: 589-594. DOI: 10.1016/j.ecolmodel.2008.11.010.

Van Proosdij ASJ, Sosef MSM, Wieringa JJ, Raes N. 2016. Minimum required number of specimen records to develop accurate species distribution models. Ecography 39: 542-552. DOI: 10.1111/ecog.01509. 
Van Vuuren D, den Elzen M, Lucas P, Eickhout B, Strengers B et al 2007. Stabilizing greenhouse gas concentrations at low levels: An assessment of reduction strategies and costs. Clim Chang 81: 119. 159. DOI: $10.1007 / \mathrm{s} 10584-006-9172-9$.

Velazco SJE, Galvão F, Villalobos F, DeMarco JP. 2017. Using worldwide edaphic data to model plant species niches: An assessment at a continental extent. PLoS ONE 12(10): e0186025. DOI: 10.1371/journal.pone.0186025.

Walther GR. 2003. Plants in a warmer world. Perspect Plant Ecol Evol Syst 6: 169-185. DOI: 10.1078/1433-8319-00076.

Ward G, Hastie T, Barry S, Elith J, Leathwick JR. 2009. Presence-only data and the em algorithm. Biometrics 65 (2): 554-563. DOI: 10.1111/j.1541-0420.2008.01116.x.

Warren DL, Seifert SN. 2011. Ecological niche modeling in Maxent: The importance of model complexity and the performance of model selection criteria. Ecol Appl 21:335-342. DOI: 10.1890/10-1171.1.

Way DA, LaDeau SL, McCarthy HR, Clark JS, Oren R, Finzi AC, Jackson RB. 2010. Greater seed production in elevated CO2 is not accompanied by reduced seed quality in Pinus taeda L. Glob Chang Biol 16: 1046-1056. DOI: 10.1111/j.1365-2486.2009.02007.x.

Wintle BA, Elith J, Potts J. 2005. Fauna habitat m.odelling and mapping: a review and case study in the Lower Hunter Central Coast region of NSW. Austral Ecol 30: 719-738. DOI: 10.1111/j.14429993.2005.01514.x.
With KA (2002) The landscape ecology of invasive spread. Conserv Biol 16 (5): 1192-1203. DOI: 10.1046/j.1523-1739.2002.01064.x

Wong KM. 1982. Critical observations on Peninsular Malaysian Selaginella. Gard Bull Sing 35(2): 107-135

Wong KM. 2010. Selaginellaceae. In Parris BS, Kiew R, Chung RKC, Saw LG, Soepadmo E (eds). Flora of Peninsular Malaysia Series 1. Ferns and Lycophytes. Malayan Forest Records No. 48. FRIM, Kepong, Selangor.

Yackulic CB, Chandler R, Zipkin EF, Royle JA, Nichols JD, Campbell Grant EH, Veran S. 2013. Presence-only modelling using Maxent: When can we trust the inferences?. Methods Ecol Evol 4 (3): 236243. DOI: $10.1111 / 2041-210 x .12004$.

Youden WJ. 1950. Index for rating diagnostic tests. Cancer 3 (1): 32-35. DOI: 10.1002/1097-0142(1950)3:1<32::AIDCNCR2820030106>3.0.CO;2-3.

Zalewski A, Michalska-Parda, A, Bartoszewicz, M, Kozakiewicz, M. \& Brzezinski M. (2010) Multiple introductions determine the genetic structure of an invasive species population: American mink Neovison vison in Poland. Biol Conserv 143: 1355-1363. DOI: 10.1134/S2075111717010064.

Zhang XC, Nooteboom HP, Kato M. 2013. Selaginellaceae. In: Wu ZY, Raven PH, Hong DY (eds). Flora of China, Vol. 2-3 (Pteridophytes). Science Press, Beijing \& Missouri Botanical Garden Press, St. Louis. 